Portland State University

PDXScholar

Winter 4-16-2019

\title{
The Interactive Effect of Temperature and Salinity in the Nile Tilapia (Oreochromis niloticus)
}

Rachel Marie Palmer

Portland State University

Follow this and additional works at: https://pdxscholar.library.pdx.edu/open_access_etds

Part of the Biology Commons

Let us know how access to this document benefits you.

\section{Recommended Citation}

Palmer, Rachel Marie, "The Interactive Effect of Temperature and Salinity in the Nile Tilapia (Oreochromis niloticus)" (2019). Dissertations and Theses. Paper 4940.

https://doi.org/10.15760/etd.6816

This Thesis is brought to you for free and open access. It has been accepted for inclusion in Dissertations and Theses by an authorized administrator of PDXScholar. Please contact us if we can make this document more accessible: pdxscholar@pdx.edu. 
The Interactive Effect of Temperature and Salinity in the Nile Tilapia (Oreochromis

niloticus)

by

Rachel Marie Palmer

A thesis submitted in partial fulfillment of the

Requirements for the degree of

Master of Science

in

Biology

Thesis Committee:

Bradley A. Buckley, Chair

Jason E. Podrabsky

Deborah A. Duffield

Portland State University

2019 


\begin{abstract}
Frequent measures that aim to identify the tolerance of an organism to various environmental conditions rely on the mortality of said organism. However, the effects of sub-lethal stress can be just as important to consider as they may give rise to how an organism may live in such an environment (growth, reproduction, etc.). Coping with changes in environmental conditions can have a high energy cost. Even starting a cellular stress response alone has proven to be costly. It is therefore reasonable that organisms in stressful situation will dedicate energy sources to survival mechanisms, and downregulate non-necessary activities like growth, and reproduction.
\end{abstract}

As a tropical freshwater species, Nile Tilapia are subject to both Winter Stress Syndrome and saltwater intrusion as global climate change progresses, making them an ideal model organism. In order to test the physiological limits of this species, we exposed Nile Tilapia to a variety of treatments (two temperatures: $21^{\circ} \mathrm{C} \& 14^{\circ} \mathrm{C}$, three salinities: 0ppt, 16ppt, 34ppt) for one hour. By manipulating both temperature and salinity simultaneously I hoped to shed light on the future of this species as global climate change progresses.

Cell cycle arrest can occur at cellular checkpoints such as the ones located at G1 or G2/M. Monitoring the DNA replication process is crucial to cellular activities, and disruptions such a cell size issues or DNA damage can cause this process to stop indicating the presence of sub-lethal stress. There were no significant changes in the proportions of cells in G1, S, or G2 due to an increase of salinity in warm water. In cold water, there was a steady decrease of the percentage of cells in G1 as salinity increased suggesting cell cycle arrest is occurring at a different checkpoint. A significant increase 
in the number of cells in $\mathrm{G} 2$ in response to cold temperature was found, however, this effect was not made greater by the addition of salinity. Increasing number of cells in G2/M suggests that there is cell cycle arrest occurring at the G2/M checkpoint.

The concentrations of three proteins involved in the regulation and arrest of the cell cycle were measured in gill tissue by dot blotting. Western blotting was performed to ensure the specificity of the protein antibodies. Three proteins of interest were chosen due to their roles in regulating cell cycle proliferation (Proliferating Cell Nuclear Antigen), growth arrest (Growth Arrest and DNA Damage-45) and programmed cell death (p53).

Proliferating Cell Nuclear Antigen (PCNA), Gadd45, p53 all showed significant decreases in concentration in gill tissue exposed to saltwater (34 ppt) in the warm temperature treatment. There was no significant effect of salinity within the cold temperature treatment for any of the proteins tested.

The CCAAT/Enhancer-binding proteins (C/EBP) are a class of transcription factors that act upon cellular proliferation and differentiation. C/EBP- $\delta$ is the specific protein that is activated in response to stress stimuli. There were no significant differences observed in $\mathrm{C} / \mathrm{EBP}-\delta$ concentrations in gill tissue. 


\section{Dedication}

This thesis is dedicated to my family who have always supported me in all of my crazy endeavors. For my loving brother Mitch Palmer, who kept me alive throughout my bachelor's degree by being the best roommate and confidant I could have ever asked for. I would like to thank my amazing mother, Teri Lewis. Everything I have learned how to overcome in life, I have learned from watching your amazing strength. In all of my moments of weakness you were always by my side, cheering me on, willing to lend an ear to listen and offer sage advice. You are, have always been, and will always be my source of strength and confidence in my life. Thank you for shaping me into the person I am today, and for being my best friend in life. I would not be where I am today without you. I love you mama.

I would also like to take this space to thank my amazing and supportive partner Oliver Light, without whom I would have certainly lost my sanity in the last few years. Every day of this life is made infinitely better knowing that you are by my side. Thank you for walking through this crazy adventure of life beside me, experiencing every stressful, tear-filled night as your own and celebrating each success with as much joy and love as can be.

Lastly, I would like to thank all of my family who have helped me survive up to this point. In particular, my brother Mitch Palmer who was my faithful roommate all throughout my undergraduate and a fierce friend, Don and Pam Holthofer who never stopped believing in me, and my grandfather Mark Hanschka who was unable to witness this event but whom I know was with me in spirit. 


\section{Acknowledgements}

First, I would like to start off by thanking my incredible advisor, Dr. Brad Buckley. Dr. Buckley was the best advisor I could have found, and throughout the entire time of being my advisor has shown me immense patience and trust. I am so lucky to have been accepted into his laboratory, given the opportunity to design this project and find a wonderful group of undergraduates to work with. I would also like to thank my committee members, Dr. Deborah Duffield and Dr. Jason Podrabsky, for their continued support and guidance over the past two years. They have helped with everything from troubleshooting assays, writing, and career guidance. Although I was the only graduate student in the laboratory at this time, I cannot say that I was alone. I had the utmost pleasure of working with a large group of phenomenal undergraduate students: Braden Burdekin, Leanna Williams, Charlee McGuire, Kate Posner, Saige Fultz, Parker Lewis and Mohamed Ali. I would also like to thank the faculty and staff of Portland State's Biology department for welcoming me into their family for the last two years. I feel immensely lucky to have found such a great group of people. 


\section{Table of Contents}

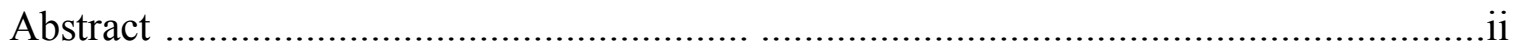

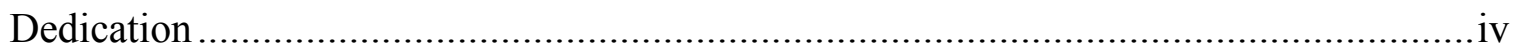

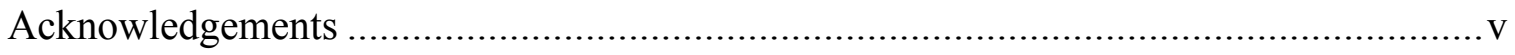

List of Tables ...............................................................................................

List of Figures ...............................................................................................

Chapter 1: Overview and Background ….............................................................. 1

Chapter 2: Flow cytometry analysis of the interactive effect of salinity and temperature on the cell cycle and apoptosis in Nile Tilapia, Oreochromis niloticus. ...............8

Figures \& Tables for Chapter 2 ........................................................................ 23

Chapter 3: The interactive effect of salinity and temperature on p53, Gadd45 and Proliferating Cell Nuclear Antigen (PCNA) in Nile Tilapia, Oreochromis

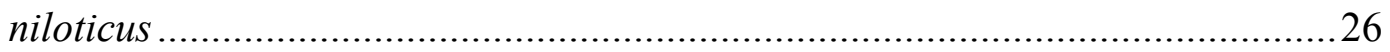

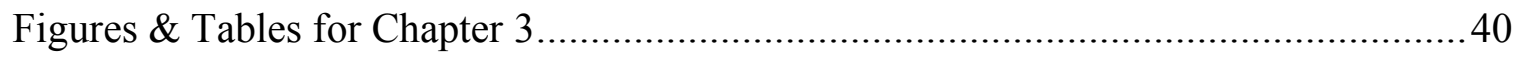

Chapter 4: The response of CCAAT/enhancer binding protein- $\delta(\mathrm{C} / \mathrm{EBP}-\delta)$ to salinity and temperature in Nile Tilapia, Oreochromis niloticus.................................44

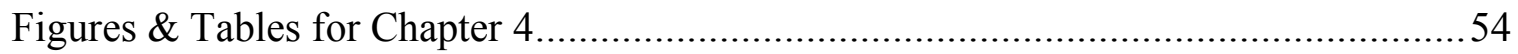

Chapter 5: Conclusions and Future Directions ................................................55

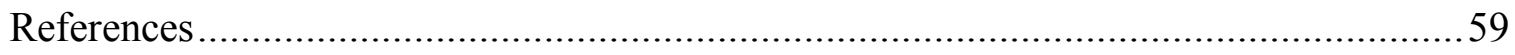




\section{List of Tables}

Table 1: Experimental design of stress tests and sample size for each treatment.

Table 2: List of p-values of all comparisons across groups for the proportions of spleen cells in the G1 phase.

Table 3: List of p-values of all comparisons across groups for the proportions of spleen cells in the $\mathrm{S}$ phase.

Table 4: List of p-values of all comparisons across groups for the proportions of spleen cells in the G2 phase.

Table 5: List of p-values of all comparisons across groups for gill PCNA concentration.

Table 6: List of p-values of all comparisons across groups for gill Gadd45 concentration.

Table 7: List of p-values of all comparisons across groups for gill PCNA concentration excluding outliers.

Table 8: List of p-values of all comparisons across groups for gill p53 concentration.

Table 9: List of p-values of all comparisons across groups for gill $\mathrm{C} / \mathrm{EBP}-\delta$ concentration. 


\section{List of Figures}

Figure 1: Nile Tilapia (Oreochromis niloticus) juvenile length and weight data.

Figure 2: Cell cycle proportions for G1, S, and G2 phases in spleen cells of the Nile Tilapia after one hour of exposure to salinity and low temperature stress treatments.

Figure 3: PCNA expression in the gill tissue of the Nile Tilapia after one hour of exposure to salinity and low temperature stress treatments.

Figure 4: Gadd45 expression in the gill tissue of the Nile Tilapia after one hour of exposure to salinity and low temperature stress treatments.

Figure 5: Gadd45 expression in the gill tissue of the Nile Tilapia after one hour of exposure to salinity and low temperature stress treatments, excluding outliers.

Figure 6: p53 expression in the gill tissue of the Nile Tilapia after one hour of exposure to salinity and low temperature stress treatments.

Figure 7: $\mathrm{C} / \mathrm{EBP}-\delta$ expression in the gill tissue of the Nile Tilapia after one hour of exposure to salinity and low temperature stress treatments. 


\section{Chapter 1: Overview and Background}

Global climate change is altering the environment of aquatic species in a variety of ways that strongly influence the physiology of these species. Abiotic factors that are often independent of each other become related through the effects of global climate change. Global climate change has increased global temperatures at a rate of $0.2^{\circ} \mathrm{C}$ per decade for over 30 years (Hansen et al 2006). Although this change has been worldwide, it is affecting land masses differently than water masses. Notably, over the last 100 years, the upper levels of the ocean have experienced an increase of $0.6^{\circ} \mathrm{C}$ (Pachauri 2007). The temperature change is not the only abiotic factor being altered due to climate change. When environmental $\mathrm{CO}_{2}$ interacts with seawater, an increase in carbonate and hydrogen ions occurs (Feely et al 2009). The increase in hydrogen ions subsequently leads to ocean acidification (Feely et al 2009). Global climate change has both direct, and indirect impacts on the environment. For example, increased concentrations of greenhouse gases have the potential to intensify coastal winds, leading to an increase in coastal upwelling (Bakun 1990). Coastal upwelling can lead to low oxygen or hypoxic conditions when nutrient-rich, oxygen-poor water is pulled up onto continental shelves (Grantham et al 2004).

In order to fully understand how climate change will affect species we must consider multiple factors at once. Factors that do not elicit a significant effect alone, may combine with other factors to cause a more significant negative effect. In the case of the damselfish, Neopomacentrus bankieri, tidal movement alone was not a significant factor but when combined with temperature, they caused a greater negative effect than temperature alone (Wenger et al 2016). Without understanding how multiple factors will 
affect species we cannot accurately determine how species will react to global climate change.

Aquatic organisms are particularly affected by changes in temperature, $\mathrm{pH}$, and salinity. Although Global Climate Change leads to an overall increase in temperature, it also leads to an increase in the fluctuations of temperature. Fish are ectotherms, meaning that their internal temperature closely matches that of their environmental temperature. The direct matching of internal temperature to external temperature is due to the lack of evaporation and lack of significant radiation in aquatic environments (Schmidt-Nielsen 1997). This indicates that environmental temperature fluctuations will have a direct impact on the internal temperature of the organism. Environmental temperature plays a crucial role in the distribution patterns of ectothermic species (Somero 2010), and determining the physiological limits species can help to elucidate the current and future niches that they may inhabit.

Ocean acidification caused by global climate change can have catastrophic effects of marine ecosystems. Organisms that use calcium carbonate $\left(\mathrm{CaCO}_{3}\right)$ to build their shell or skeleton are at risk due to the increased saturation rate of calcium carbonate with an increase of $\mathrm{pH}$ (Ries et al 2009). Although the intensity of the response to decreased $\mathrm{pH}$ varied, the addition of increased temperature lead to more drastic effects across taxa (Kroeker et al 2013).

It is rare for an aquatic organism to live in an environmental salinity concentration that is isotonic with its internal level approximately $30-40 \%$ the concentration of saltwater. Most organisms live in freshwater which is found in rivers and lakes, brackish water which is found in estuarine areas, or saltwater which is found in oceans and seas. This means 
organisms that regulate their internal ion concentrations are constantly undergoing the process of osmoregulation. Febry and Lutz 1997 concluded that although individuals living in isosmotic conditions still expend energy on osmoregulation, the relative costs of osmoregulation in freshwater or saltwater increase 3-4 times faster when fish are actively swimming, or when the energetic demand increases.

As strictly aquatic creatures, fish face unique challenges as a part of their habitat. The ability for fish to regulate or conform to environmental conditions varies depending on the abiotic factor meaning that although fish are ectotherms (or thermal conformers) they are regulators of their internal osmolality. Tropical ectotherms are more threatened by climate change because, in most cases, these organisms are already living close to, or at, their upper thermal tolerance limits (Somero 2010). In order to compensate for these thermal changes species will either need to acclimate or exhibit a distribution shift.

As sea levels rise, seawater is introduced into freshwater systems causing sufficiently large fluctuations in salinity and temperature simultaneously that freshwater taxa are unable to acclimate (Gunter and Hildebrand 1951). Saltwater intrusion is largely studied as it related to groundwater aquifers, however, less is known about how freshwater systems and the organisms that reside in them will be affected by this change. Coastal regions are expected to change dramatically, however, more studies must be done to determine how rivers just off of the coast will be affected. The organisms residing in rivers proximal to the coast may experience a significant salinity change.

Proximal causes of salinity-induced stress and mortality include cell shrinkage leading to damage of the membranes of mitochondria, the organelles that regulate programmed cell death (Berg at al. 2012). When a freshwater fish enters a saltwater 
environment a switch in cell volume regulation must be made (Schmidt-Nielsen et al. 1997). In freshwater, an organism contains more ions in their cells than in the environment, so in order to maintain homeostasis the organism must be conserving ions while also getting rid of excess water (Schmidt-Nielsen et al. 1997).

When that organism enters a saltwater environment, the organism encounters the opposite problem. The external environment now contains more ions than the cell, and so the organism must be constantly conserving water, while excreting excess ions (SchmidtNielsen et al. 1997). If an organism is not able to compensate for the salinity change then its cells will lose water and shrink. This volume change can cause the cell membrane to break, and the increased salinity can denature crucial proteins (Berg at al. 2012). When a cell is no longer able to maintain homeostasis an apoptotic pathway is initiated by the mitochondria (Berg at al. 2012).

Winter stress syndrome is a significant cause of mortality in freshwater fishes (Hurst 2007). These deaths are often referred to a 'winterkills', and occur in a variety of freshwater systems including lakes, reservoirs and rivers (Hurst 2007). A decrease in temperature can lead to mortality through a variety of ways including intrinsic, abiotic, and ecological factors (Hurst 2007). Examples of these factors include immunosuppression, predator avoidance, and prey capture, however, the most notable is how thermal stress affects the cells of an organism (Hurst 2007).

Proximal causes of temperature-induced stress and mortality include decreased osmoregulation ability and damage to the membranes of mitochondria (Schmidt-Nielsen et al 1997), the organelles that regulate programmed cell death. Organisms that are acclimated to low temperatures are able to compensate by either reducing permeability of 
the mitochondrial membrane, or by increasing the activity of ion pumps (Hurst 2007). Fish that are unable to compensate become stressed when these mechanisms are unable to maintain homeostasis (Schmidt-Nielsen et al 1997). When this happens cell membranes are either rendered useless, or have structural damage associated with increased rigidity (Schmidt-Nielsen et al 1997). When a cell is no longer able to maintain homeostasis an apoptotic pathway is initiated by the mitochondria (Berg et al. 2012).

Nile tilapia (Oreochromis niloticus) provide an ideal model to study the combined effect of temperature and salinity as it inhabits freshwater systems that are vulnerable to sea level rise, and winter stress syndrome, and also due to the large amount of genetic information available for this species (Hassan et al 2013). Tilapia are one of the largest commercial fisheries, so understanding how these phenomena will affect their populations will be crucial for cultures that depend on the nutrition they provide. Tilapia are of huge economical importance and Tilapia farming has increased $12-15 \%$ annually in the past two decades due to technological improvements (Lim \& Webster 2006). Although most Tilapia species are endemic to the tropical freshwaters of Africa, Jordan and Israel, Tilapia are now cultured in both fresh and salt waters, and tropical, subtropical and temperate environments (Lim \& Webster 2006).

Due to their ability to be reared in multiple environments, Nile Tilapia are a popular model organism for studying the effect of salinity and temperature on Nile Tilapia. Previous studies have identified this response by measuring glucose levels (Barcellos et al 1999), the endocrine system (Breves et al 2010) including cortisol levels (Kammerer et al 2010), immune response (Chebaani et al 2014), and growth rates and feed utilization (Likongwe et al 1996). The heritability of cold tolerance has also been of great interest, 
especially due to the economic costs of winter mortality (Charo-Karisa et al 2005). Due to the economic need to decrease mortality of the Nile Tilapia during winter months, many studies have altered environmental conditions hoping to improve cold tolerance. Hassan et al 2013 found that by acclimating Nile Tilapia to isotonic salinity the disruption of ionic balance caused by cold stress was lessened when compared to individuals acclimated to freshwater.

Investigating the tolerances of the Nile Tilapia is not only important for the fisheries profession, but also creates awareness of their potential as an invasive species. In the United States alone, the Nile Tilapia is already invasive in many warmer freshwater systems. By investigating their tolerance to increased salinity and decreased temperature we can assess their threat to other habitats. As an invasive species, Tilapia compete for resources utilized by native fish, thereby exerting pressure on native species (Zamabrano et al. 2006). Nile Tilapia have also been documented preying on native amphibians and juvenile fish of other species (Zamabrano et al. 2006).

This study seeks to better understand how the combined effect of temperature and salinity affects an aquatic organism. Previous studies have investigated the effect of either temperature or salinity on cellular processes. To better predict whether Tilapia and other freshwater species will exhibit a shift in distribution, we need to better understand how the severity of salinity and temperature stress, not only separately but in combination, will affect these species. A more holistic approach will help to deepen our understanding of the consequences of climate change and expand our knowledge of which taxa will be 'winners' and which will be 'losers'. 
Changes in the concentration of proteins (p53, GADD45 and PCNA) that assist in the regulation of the cell cycle in response to environmental changes was studied in Chapter 2. Other means of controlling cell cycle arrest and apoptosis include the protein family CCAATT/enhancer binding protein (C/EBP). Chapter 3 investigates the response of $\mathrm{C} / \mathrm{EBP}-\delta$ to changes in environmental salinity and temperature. In Chapter $4 \mathrm{I}$ investigated how salinity and temperature effect the cell cycle and potentially cause cell cycle arrest. Cell cycle progression and arrest is heavily regulated, often by proteins. Each of these are presented in manuscript format. 


\section{Chapter 2: Flow cytometry analysis of the interactive effect of salinity and temperature on the cell cycle and apoptosis in Nile Tilapia, Oreochromis niloticus}

Abstract

Frequent measures that aim to identify the tolerance of an organism to various environmental conditions rely on the mortality of said organism. However, the effects of sub-lethal stress can be just as important to consider as they may give rise to how an organism may live in such an environment (growth, reproduction, etc.). Coping with changes in environmental conditions can have a high energy cost. Even starting a cellular stress response alone has proven to be costly. It is therefore reasonable that organisms in stressful situation will dedicate energy sources to survival mechanisms, and downregulate non-necessary activities like growth, immune responses and reproduction.

Cell cycle arrest can occur at cellular checkpoints such as the ones located at G1 or G2/M. Monitoring the DNA replication process is crucial to cellular activities, and disruptions such as cell size issues or DNA damage can cause this process to stop. Sudden changes in salinity and temperature can damage DNA or cause an increase in reaction times. I subjected the Nile Tilapia (Oreochromis niloticus) to a variety of salinity and temperature treatments. By analyzing the DNA content in cells after one hour of exposure I was able to assess the proportion of cells in each cell phase.

There were no significant changes in the proportions of cells in G1, S, or G2 due to an increase of salinity in warm water. In cold water there is a steady decrease of the percentage of cells in G1 as salinity is increased. A significant increase in the number of cells in G2 in response to cold temperature was found, however, this effect was not made greater by the addition of salinity. Increasing number of cells in G2/M suggests that there is cell cycle arrest occurring at the G2/M checkpoint. Salinity changes in warm 
temperature had no significant effect on cell cycle proportions. Cold temperature exposure lead to significant increase in the proportion of cells in G2, with no significant changes as salinity was increased. 


\section{Introduction}

The phenomenon of abiotic factors influencing the distribution of species is well

documented. By not only understanding current distribution patterns but also the limits of species we can better predict how these patterns will change in response to global climate change (Somero 2010). Gaining valuable insight into the tolerances of various species will not only assist in the conservation of important species, but can also indicate which species have the potential to be successful invasive species. Invasive species can have drastic effects on the local fauna of a region.

Global climate change not only affects species distribution, but the stress caused due to environmental changes can affect the timing of an organism's feeding, growth and reproduction (Visser et al 2012). When investigating the effect that environmental changes have on an organism there are several ways to measure direct effects. Some of these include saltwater challenges for salinity tolerances, temperature that is leathal to $50 \%$ of individuals (or LT50) for temperature ranges, etc. However most of these measures tell you whether or not an organism is able to survive the stress, but do not do not give insight as to how the organism might live in such an environment. It is important to study which stresses are lethal to organisms, however, it is also important to consider sub-lethal stresses.

The effects of sub-lethal stress on fishes has been widely studied in response to a variety of stressors, especially those pertaining to aquaculture. Although the duration of some stressors may be short, their effects can drastically reduce the fitness of an organism. The ability for an organism to respond quickly to these stresses is often crucial to its survival. Juvenile chinook salmon subjected to a rapid increase in water temperature 
showed an increase in plasma corticoid concentration after only 24 minutes, that lasted for 3 hours (Strange et al 2011). The ability for salmon to rapidly induce a stress response (plasma corticoid concentration) allows for faster regulation of thermal changes. This study shows that thermal stress can be identified in both short-term and long-term time frames.

Even the act of triggering a cellular stress response is a costly process, as is the return to homeostasis (Schreck 2009). When an organism is diverting energy to upregulating a stress response, less energy is available for other processes. In juvenile steelhead only subjected to three consecutive 2-minute disturbances, the available energy for other activities was reduced by one-quarter (Barton \& Schreck 1987). Processes that are not immediately needed for survival are typically shut off such as reproduction (Schreck et al 2001), and growth (McCormick et al 1998). When an organism stops the replication of DNA and cellular division this is commonly referred to as cell cycle arrest.

Studies involving cell cycle arrest often tie into process not needed for survival, such as DNA damage caused by chemotherapeutic drugs (Linke et al 1996) or UV radiation (Gentile et al 2003) due to their potential to stop the spread of un-regulated cellular proliferation in cancer. Cell cycle arrest does not only occur in response to DNA damage. Linke et al (1996) found that the protein p53 was able to cause reversible cell cycle arrest at the $\mathrm{G}_{0} / \mathrm{G}_{1}$ checkpoint even when there was no detectable DNA damage that had occurred.

The ability of a cell to divide into two genetically identical daughter cells relies upon accurate DNA replication and division (Murray 1992). In order to complete this process, a cell goes through several phases of the cell cycle. The order of the stages of the 
cell cycle are as follows: $\mathrm{G}_{1}, \mathrm{~S}, \mathrm{G}_{2}$, and $\mathrm{M}$ (Schafer 1998). The $\mathrm{G}_{1}$ and $\mathrm{G}_{2}$ phases are gaps in the cell cycle, with $\mathrm{G}_{1}$ being the stage at which the cell is preparing for DNA synthesis (Schafer 1998). The S phase is the synthesis of DNA where the DNA content doubles from $2 \mathrm{~N}$ to $4 \mathrm{~N}$ (Schafer 1998). $\mathrm{G}_{2}$ phase is a second gap following the $\mathrm{S}$ phase, where cells are preparing for mitosis (Schafer 1998). During the M phase mitosis occurs, and the cell splits into two daughter cells (Schafer 1998).

There are several cell cycle checkpoints located at various stages in the cell cycle. Cell cycle checkpoints are widely used because of their ability to recognize DNA replication errors. The loss of function of checkpoints has been documented in the alteration of normal cells into cancer cells (Elledge 1996). There are three cell cycle checkpoints: the G1 checkpoint (or the major checkpoint), the G2/M checkpoint and the metaphase checkpoints or spindle checkpoint (Elledge 1996).

Cells can stop at any of the checkpoints for various reasons, including an increase or decrease in cell size or DNA damage (Barnum \& O’Connell 2014). Cell size is regulated to ensure that each daughter cell has the exact amount of biosynthetic and genetic materials (Barnum \& O'Connell 2014). This type of cell cycle control is crucial for multicellular organisms to regulate proper organ size and nutrient distribution (Barnum \& O’Connell 2014). When cells are too small they can cause cell cycle arrest at both the G1 and G2/M checkpoints (Barnum \& O’Connell 2014).

DNA damage can occur due to intrinsic or extrinsic mechanisms. When DNA damage is detected, a signal is sent that can arrest cells. The phase in which cells are arrested depends on where the DNA damage is sensed (Elledge 1996). Cell cycle arrests in G1 phase prevent cells from entering the S phase (Elledge 1996). If cells are in the S 
phase when DNA damage is detected, DNA synthesis can be slowed down (Elledge 1996). The $\mathrm{S}$ phase is a very vulnerable time for DNA damage since the damage must be repaired or it can physically block polymerases (Barnum \& O'Connell 2014). Lastly, if cells are in the G2 phase during DNA damage, they are arrested and can initiate DNA repair pathways (Elledge 1996).

Effects of sub-lethal stress have been documented to cause cell cycle arrest and apoptosis in the liver cells of the Antarctic fish Trematomus bernacchii (Sleadd et al 2014). The proportion of cells in G1 phase decreased in response to heat exposure with a simultaneous increase in the number of apoptosis cells observed (Sleadd et al 2014). By assessing the changes in cell cycle in response to a sub-lethal stress we can get a better grasp on whether or not that organism can not only survive a stress but continue to grow, find food, avoid predation and reproduce.

This study investigates changes in cell cycle response to salinity stress, low temperature stress, and the simultaneous exposure to these stresses in the Nile Tilapia (Oreochromis niloticus). After a direct transfer from freshwater into 2/3 strength saltwater, the proportion of gill epithelial cells of the Mozambique Tilapia (Oreochromis mossambicus) in G2 increased, indicating a G2/M cell cycle arrest occurred (Krammer et al 2009). When Nile Tilapia were exposed to the low temperature of $18^{\circ} \mathrm{C}$ cells showed an initial suppression of DNA synthesis, and finally stabilized at $30 \%$ of the level of DNA synthesis in the control group (Chen \& Yew 1988). The cellular responses of the Nile Tilapia to increased salinity and low temperature are of great use for aquaculture purposes, and to better predict the invasive potential of this species in non-native habitats. 
By subjecting individuals to a variety of salinity and temperature treatments the cellular responses can be measured. 


\section{Methodology}

\section{Animals}

All rearing protocols and experiments followed the rules and regulations set by IACUC. Before obtaining and handling fish, all protocols were approved by the Portland State University Animal Care and Use Committee. Fingerling Nile Tilapia (Oreochromis niloticus) were obtained from Greenhill Gardens (Eugene, Oregon, USA) and were reared for 6 months at Portland State University. Tilapia were fed ad libitum daily with $1.5 \mathrm{~mm}$ pelleted commercial feed consisting of $33.0 \%$ crude protein, $10.0 \%$ crude fat, and $2.0 \%$ crude fiber. All fish were kept on a 12 hour light: 12 hour dark photoperiod, at $22^{\circ} \mathrm{C}$ in freshwater $(\sim 0 \mathrm{ppt})$. Water conditions were monitored daily.

Fish were common gardened (reared in the same tank and conditions) for at least two weeks prior to use exposure treatments. Fish were then transferred to treatment tanks, with 10 fish per tank. One tank was used as a temperature and salinity control $\left(22^{\circ} \mathrm{C}\right.$ and $0 \mathrm{ppt}$ ), while the other five treatments consisted of $22^{\circ} \mathrm{C}$ and $14 \mathrm{ppt}, 22^{\circ} \mathrm{C}$ and $34 \mathrm{ppt}$, $14^{\circ} \mathrm{C}$ and $0 \mathrm{ppt}, 14^{\circ} \mathrm{C}$ and $14 \mathrm{ppt}$, and $14^{\circ} \mathrm{C}$ and $34 \mathrm{ppt}$, as illustrated in Table 1 . Salt concentrations were made in the lab by mixing deionized tap-water with Instant Ocean Sea Salt and concentrations were measured using a hydrometer. Fish were held in the treatment tanks for $1 \mathrm{~h}$, and then euthanized via rapid freeze and cervical dislocation. Spleen tissues were collected. Spleen tissues were used for flow cytometry analysis due to the ability to easily separate cells.

Tissue Preparation 
Spleen tissues were incubated in a concentration of collagenase of 5 units $/ \mathrm{mL}$ of cell suspension buffer $\left(292.5 \mathrm{mmol} \mathrm{1}^{-1} \mathrm{NaCl}, 5 \mathrm{mmol} \mathrm{1}^{-1} \mathrm{KCl}, 2.5 \mathrm{mmol} \mathrm{1}^{-1} \mathrm{MgCl}_{2}, 3 \mathrm{mmol}\right.$ $1^{-1} \mathrm{CaCl}_{2}, 2 \mathrm{mmol}^{-1} \mathrm{NaHCO}_{3}, 2 \mathrm{mmol} 1^{-1} \mathrm{NaH}_{2} \mathrm{PO}_{4}, 5 \mathrm{mmol}^{-1}$ glucose and $50 \mathrm{mmol}$ $1^{-1}$ Hepes, [pH 7.8]) for $1 \mathrm{hr}$ under constant shaking to dissociate cells. Cell suspension buffer was made in the laboratory following the protocol previously defined by Sleadd et al (2014). Cells were then strained through a cell sieve, centrifuged at $13,000 \mathrm{x} g$ for 10 minutes, then re-suspended in $100 \%$ Ethanol and stored at $4^{\circ} \mathrm{C}$.

\section{Flow Cytometry}

Flow cytometry protocol was adapted from Sleadd et al (2014). Spleen cells were pelleted by gentle centrifugation, and ethanol removed. Cells were then washed in $1 \mathrm{xPBS}$, and then re-suspended in staining solution containing propidium iodine $(0.02 \%$ DNase-free RNase, $0.005 \%$ propidium iodine in 1xPBS). Cells were incubated in staining solution for 30 minutes on ice, and then analyzed using a BD Accuri ${ }^{\mathrm{TM}}$ C6 Flow Cytometer. Utilizing C software (BD Accuri ${ }^{\mathrm{TM}}$ ) cell data was collected and analyzed. Propidium iodine fluorescence was used to determine DNA content, which allow for the drawing gates around the populations of the cells of interest. In order to remove any potentially clumped cells, double discrimination was utilized. By measuring peaks within our gate of interest, percentages and total counts of cells within each cell stage were recorded. 


\section{Statistics}

All statistical analysis was performed using Microsoft Excel 2010. To compare the differences in mean percentage for each cell cycle phase, t-tests were used. Due to unequal sample sizes a two-sample t-test assuming unequal variances was performed.

Only two-tailed $p$-values were used as the final $p$-value, and any value under $\mathrm{P}=0.05$ was considered statistically significant. All treatment groups were compared against all other treatment groups for the same cell cycle phases. 


\section{Results}

The effects of salinity and temperature on cell cycle phases were complex and are visualized in Figure 2.

\section{Cell Cycle: G1 Phase}

After one hour there were no significant changes in the percentage of cells in G1 with increased salinity in warm water, Table 2 . In cold water, there was a trend of decreasing percentages of cells in G1 with increasing salinity. There is no significant difference between cold freshwater and cold brackish water, or cold brackish water and cold saltwater. However, there is a significant decrease in the amount of cells in G1 from cold freshwater and cold saltwater $(\mathrm{p}=0.024)$ and from warm saltwater to cold saltwater $(\mathrm{p}=0.002)$.

\section{Cell Cycle: S Phase}

There were no significant changes in the proportion of cells in the S phase, Table 3. Within the cold water treatments, the effect of increased salinity was significant. The cold saltwater treatment had significantly higher cells in S phase when compared to both cold freshwater $(\mathrm{p}=0.026)$ and cold brackish water $(\mathrm{p}=0.039)$.

\section{Cell Cycle: G2 Phase}

Cells in the G2 phase were the only ones to have significant differences in warm water with increasing salinity, Table 4. In comparison to the control (warm freshwater) there were no significant changes in warm brackish water or warm saltwater. However when 
compared to the warm brackish water, there was a significant increase in the proportion of cells in the G2 phase in the warm saltwater group $(\mathrm{p}=0.002)$. All cold water treatments were significantly higher than all warm water treatments $(\mathrm{p}<.01)$. When salinity increased in the cold water groups there were no significant changes. 


\section{Discussion}

All phases of the cell cycle measured had significant differences in response to some of the exposures performed. For the warm water treatments there were no observed changes in the proportions of G1 in response to increased salinity. Therefore there was no evidence for G1 cell cycle arrest due to increasing salinity in Nile Tilapia after one hour of exposure.

In the cold water treatments, however, there was a trend of a steady decline in the percentage of cells in the G1 phase with an increase in salinity. In this cell phase brackish water served as a mid-range treatment, since it was not significantly different than any other cold water treatment. The proportion of cells within the S phase significantly increased in the cold saltwater group, and this in concert with the G1 data suggest that cells are continuing to leave the G1 phase and entering the S phase in response to cold saltwater.

Lastly, there was a significant increase in the percentage of cells in G2 was observed across all cold water treatments in comparison to all warm water treatments. Increasing salinity within the cold water groups had no effect on the proportions of cells in G2 however. These data suggest that there is cell cycle arrest at the G2/M checkpoint in response to cold temperature, but that this effect is not magnified by the addition of increased salinity.

Previous studies have identified a similar trend of increasing cells in the G2 phase due to cell cycle arrest at the G2/M checkpoint in response to salinity stress (Krammer et al 2009). However, this study revealed similar results due to low temperature stress. 
Although the previous salinity stress utilized was $2 / 3$ saltwater, we were not able to achieve the same results even in our full strength saltwater exposure in warm water.

Studies on low temperature in Tilapia have revealed a rapid initial suppression in DNA synthesis (Chen \& Yew 1988) when compared to the control. Although not significant, there does appear to be a lower percentage of cells in the S phase of the cold freshwater and cold brackish water treatment compared to the control. However the cold saltwater treatment had significantly higher percentage of cells in the S phase compared to other cold water treatments, but no significant change when compared to the control indicating that with longer duration a significant change might be revealed.

There are a few points that are worth mentioning. It is important to note that significant changes in cell cycle were able to be observed after only one hour of stress exposure since no acclimation time was allowed, where in other studies longer durations were used. I also chose to analyze spleen tissue rather than gill tissue, which was used in the Krammer et al (2009) study. Changes in gill epithelial cells in response to increased salinity could be due to the direct interaction that those cells have with the environment, and their function in osmoregulation.

The spleen is involved in storage, and as needed, supply of red blood cells to the organism's circulation (Yamamoto et al 1985) and the release of store red blood cells is typically in response to exercise or hypoxic conditions (Yamamoto et al 1985). The spleen thus not only has it's own blood supply to function, but also functions in storage of excess blood. Because of this, the results we observed are due to both spleen cells and red blood cells. 


\section{Figures}

Table 1: Experimental design of stress tests. Duration of exposure was 60 minutes, with control treatment being $22^{\circ} \mathrm{c}$ freshwater $(0 \mathrm{ppt})$. A sample size of 10 individuals was used for all treatments.

\begin{tabular}{|c|c|c|c|}
\hline & Freshwater (0 ppt) & Brackish (16 ppt) & Saltwater (34 ppt) \\
\hline $14^{\circ} \mathrm{C}$ & $\mathrm{n}=10$ & $\mathrm{n}=10$ & $\mathrm{n}=10$ \\
\hline $22^{\circ} \mathrm{C}$ & $\mathrm{n}=10$ & $\mathrm{n}=10$ & $\mathrm{n}=10$ \\
\hline
\end{tabular}

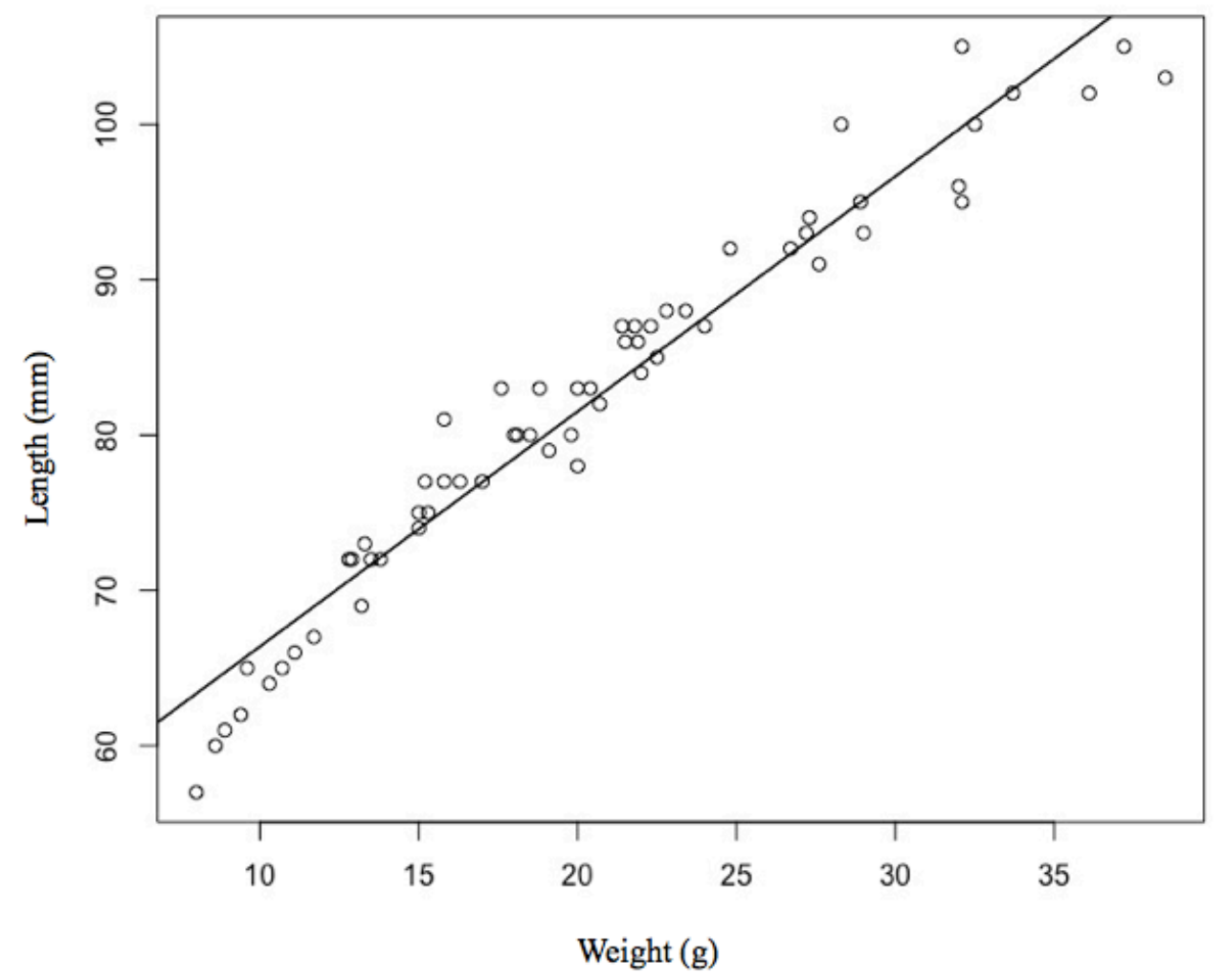

Figure 1: Length and Weight data collected from laboratory reared mixed-sex Nile Tilapia (Oreochromis niloticus). 


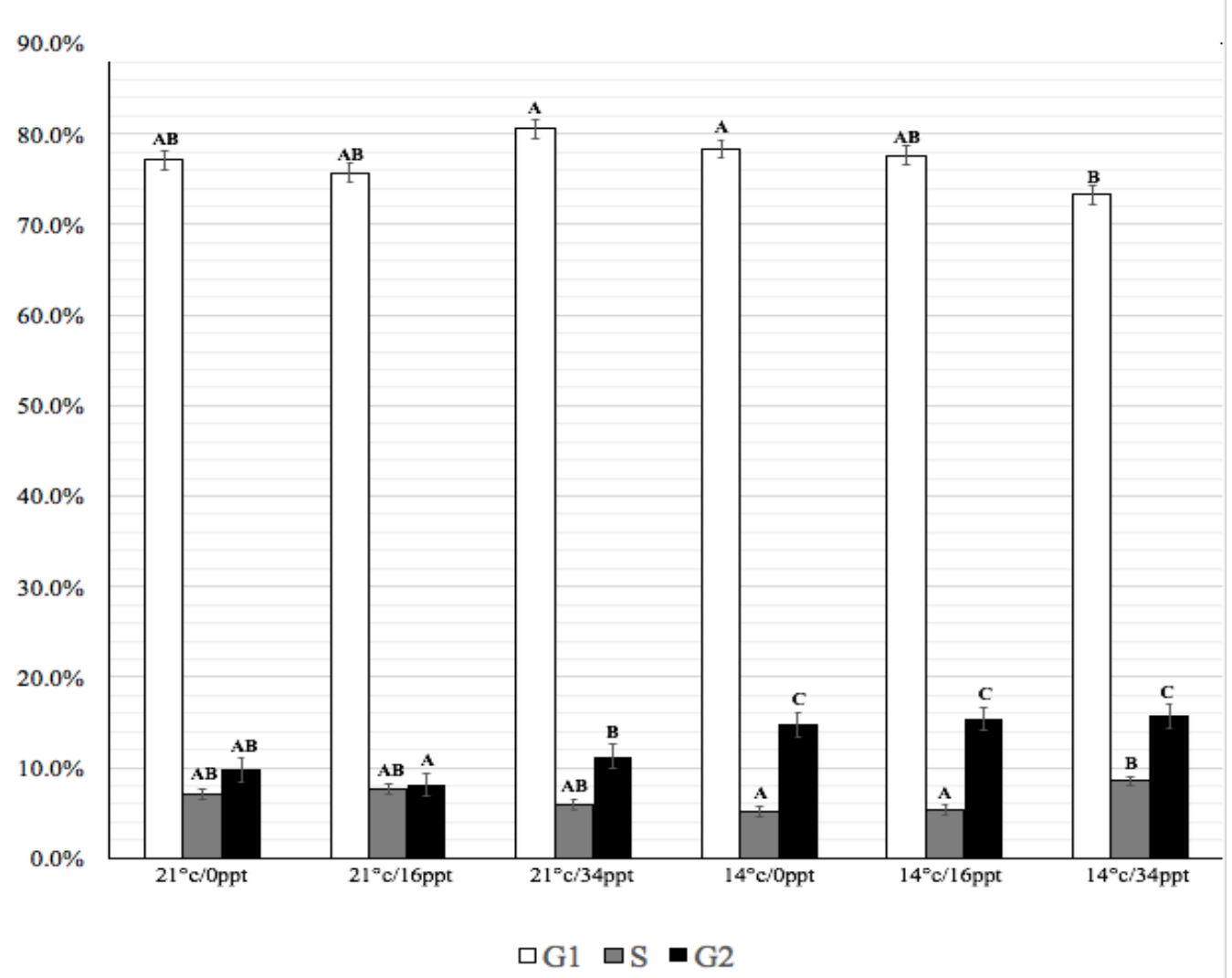

Figure 2: Graph of the percentages of cells in each cell cycle phase (G1, S, or G2) in the spleen cells of Nile Tilapia (Oreochromis niloticus) after one hour of exposure to salinity and low temperature treatment groups. Error bars indicate standard error. Different letters indicate statistically significant differences $(\mathrm{p}<0.05)$.

Table 2: List of all p-values generated from comparing proportions of Nile Tilapia (Oreochromis niloticus) spleen cells in the G1 phase from each treatment to all other treatments. Bolded values indicate statistically significant values $(\mathrm{p}<0.05)$. Grey boxes indicate repetitive comparisons.

\begin{tabular}{|l|l|l|l|l|l|}
\hline $\mathrm{G} 1$ & $21^{\circ} \mathrm{C} / 16 \mathrm{ppt}$ & $21^{\circ} \mathrm{C} / 34 \mathrm{ppt}$ & $14^{\circ} \mathrm{C} / 0 \mathrm{ppt}$ & $14^{\circ} \mathrm{C} / 16 \mathrm{ppt}$ & $14^{\circ} \mathrm{C} / 34 \mathrm{ppt}$ \\
\hline $21^{\circ} \mathrm{C} / 0 \mathrm{ppt}$ & 0.708 & 0.218 & 0.655 & 0.861 & 0.197 \\
\hline $21^{\circ} \mathrm{C} / 16 \mathrm{ppt}$ & & 0.188 & 0.452 & 0.597 & 0.483 \\
\hline $21^{\circ} \mathrm{C} / 34 \mathrm{ppt}$ & & & 0.216 & 0.229 & $\mathbf{0 . 0 0 2}$ \\
\hline $14^{\circ} \mathrm{C} / 0 \mathrm{ppt}$ & & & & 0.783 & $\mathbf{0 . 0 2 4}$ \\
\hline $14^{\circ} \mathrm{C} / 16 \mathrm{ppt}$ & & & & & 0.103 \\
\hline $14^{\circ} \mathrm{C} / 34 \mathrm{ppt}$ & & & & & \\
\hline
\end{tabular}


Table 3: List of all p-values generated from comparing proportions of Nile Tilapia (Oreochromis niloticus) spleen cells in the $\mathrm{S}$ phase from each treatment to all other treatments. Bolded values indicate statistically significant values $(\mathrm{p}<0.05)$. Grey boxes indicate repetitive comparisons.

\begin{tabular}{|l|l|l|l|l|l|}
\hline $\mathrm{S}$ & $21^{\circ} \mathrm{C} / 16 \mathrm{ppt}$ & $21^{\circ} \mathrm{C} / 34 \mathrm{ppt}$ & $14^{\circ} \mathrm{C} / 0 \mathrm{ppt}$ & $14^{\circ} \mathrm{C} / 16 \mathrm{ppt}$ & $14^{\circ} \mathrm{C} / 34 \mathrm{ppt}$ \\
\hline $21^{\circ} \mathrm{C} / 0 \mathrm{ppt}$ & 0.686 & 0.467 & 0.202 & 0.260 & 0.375 \\
\hline $21^{\circ} \mathrm{C} / 16 \mathrm{ppt}$ & & 0.191 & 0.057 & 0.084 & 0.542 \\
\hline $21^{\circ} \mathrm{C} / 34 \mathrm{ppt}$ & & & 0.440 & 0.574 & 0.089 \\
\hline $14^{\circ} \mathrm{C} / 0 \mathrm{ppt}$ & & & & 0.844 & $\mathbf{0 . 0 2 6}$ \\
\hline $14^{\circ} \mathrm{C} / 16 \mathrm{ppt}$ & & & & & $\mathbf{0 . 0 3 9}$ \\
\hline $14^{\circ} \mathrm{C} / 34 \mathrm{ppt}$ & & & & & \\
\hline
\end{tabular}

Table 4: List of all p-values generated from comparing proportions of Nile Tilapia (Oreochromis niloticus) spleen cells in the G2 phase from each treatment to all other treatments. Bolded values indicate statistically significant values $(\mathrm{p}<0.05)$. Grey boxes indicate repetitive comparisons.

\begin{tabular}{|l|l|l|l|l|l|}
\hline $\mathrm{G} 2$ & $21^{\circ} \mathrm{C} / 16 \mathrm{ppt}$ & $21^{\circ} \mathrm{C} / 34 \mathrm{ppt}$ & $14^{\circ} \mathrm{C} / 0 \mathrm{ppt}$ & $14^{\circ} \mathrm{C} / 16 \mathrm{ppt}$ & $14^{\circ} \mathrm{C} / 34 \mathrm{ppt}$ \\
\hline $21^{\circ} \mathrm{C} / 0 \mathrm{ppt}$ & 0.080 & 0.100 & $\mathbf{0 . 0 0 0 4}$ & $\mathbf{0 . 0 0 0 1}$ & $<\mathbf{0 . 0 0 0 0 1}$ \\
\hline $21^{\circ} \mathrm{C} / 16 \mathrm{ppt}$ & & $\mathbf{0 . 0 0 2}$ & $\mathbf{1 . 4 8 x 1 0}{ }^{-5}$ & $\mathbf{0 . 0 0 0 2}$ & $<\mathbf{0 . 0 0 0 0 0 1}$ \\
\hline $21^{\circ} \mathrm{C} / 34 \mathrm{ppt}$ & & & $\mathbf{0 . 0 0 3}$ & $\mathbf{0 . 0 0 9}$ & $\mathbf{0 . 0 0 0 1}$ \\
\hline $14^{\circ} \mathrm{C} / 0 \mathrm{ppt}$ & & & & 0.681 & 0.391 \\
\hline $14^{\circ} \mathrm{C} / 16 \mathrm{ppt}$ & & & & & 0.818 \\
\hline $14^{\circ} \mathrm{C} / 34 \mathrm{ppt}$ & & & & & \\
\hline
\end{tabular}




\section{Chapter 3: The interactive effect of salinity and temperature on p53, Gadd45 and Proliferating Cell Nuclear Antigen (PCNA) in the Nile Tilapia, Oreochromis niloticus \\ Abstract}

This study aims to investigate the interactive effect that salinity and temperature have on the cellular stress response of the Nile Tilapia. As a tropical freshwater species, Nile Tilapia are subject to both Winter Stress Syndrome and saltwater intrusion as global climate change progresses, making them an ideal model organism. In order to test the physiological limits of this species, we exposed Nile Tilapia to a variety of treatments. By manipulating both temperature and salinity simultaneously we can shed light as to the future of this species as global climate change progresses.

The concentrations of three proteins involved in the regulation and arrest of the cell cycle were measured in gill tissue through the utilization of dot blotting. Western blotting were performed to ensure the specificity of the protein antibodies. Proliferating Cell Nuclear Antigen (PCNA), Gadd45, p53 all showed significant decreases in concentration when exposed to saltwater (34 ppt) in the warm temperature treatment. There was no significant effect of salinity within the cold temperature treatment for any of the proteins tested.

Physiological studies that investigate PCNA, Gadd45 and p53 are often observed in mammalian cells. This study describes the responses of these proteins in a nonmammalian species, and the cellular stress response of the Nile Tilapia. Results of this study allow insight on how to improve conservation of this economically important species, and assists policy and regulation of this invasive species in non-native habitats. 


\section{Introduction}

Global climate change is altering the environment and these changes can be increases or decreases in abiotic factors (e.g temperature, salinity, $\mathrm{pH}$, oxygen availability). Changes in environmental conditions often lead to a physiological response that can be observed at the cellular level (Somero 2010). These changes are often referred to as the Cellular Stress Response (Kültz 2005). The CSR has many protein pathways that regulate cell proliferation, cell cycle arrest and apoptosis, a pathway that leads to programmed cell death. Physiological studies are crucial to predict to predict how organisms will respond to global climate change (Somero 2010).

Although global climate change can lead to an overall increase in temperature, it cal also lead to an increase in temperature fluctuations. Thermal stress, due to cold temperature, leading to mortality in a variety of fish populations has been documented for over a century (Hurst 2007). These die-offs are often referred to as 'winter-kills', and have drastic effects on fisheries (Hurst 2007). Decreases in temperature can negatively affect fish in multiple ways, including increased metabolic costs, immunosuppression and thermal stress (Hurst 2007).

Fish rarely live at their iso-osmotic point (same concentration of ion outside as internally), meaning that most are constantly trying to maintain osmotic balance while living either in fresh water (0 ppt), brackish water (16 ppt), or salt-water (34 ppt). Freshwater has a lower ionic concentration in the environment than in the internal environment of the fish which typically lies around 7-8 ppt. In freshwater environments, organisms are continuously conserving ions and excreting excess water. Brackish and salt water have a greater concentration of ions in the environment than in the internal 
environment of the organism. In this situation, fish are therefore continuously excreting excess ions and conserving water.

When a fish that typically inhabits freshwater is confronted with either brackish or saltwater they must alter their osmoregulation strategy to accommodate their new environment. If an organism cannot cope with this transfer into increased salinity and is unable to maintain homeostasis, cell shrinkage can occur and lead to damage of important cellular organelles. Increased salinity can also lead to the denaturation of important proteins, initiating the cellular stress response. The cell will enter cell cycle arrest, and if the damage is severe enough, undergo apoptosis.

Most physiological studies focus on the effect of a single stressor on an organism. However, in the environment multiple stressors are changing simultaneously. Ionpumping systems within a fish are often temperature dependent, indicating that low temperature could lead to an inability of a fish to maintain homeostasis (Hurst 2007). However a change in one abiotic factor may have an effect on another. For example, an increase in water temperature can also lead to a decrease in the ability of the water to hold oxygen. For this reason it is important to study how the simultaneous change in multiple abiotic factors may affect fishes.

The CSR can lend insight to the overall health and well-being of an individual. There are two potential pathways that are affected by the CSR: cell cycle arrest and apoptosis. These pathways, the fate of the cell, and then the fate of the organism are regulated by specific proteins. The pathways of the CSR have been activated through DNA-damaging agents, such as UV radiation, and have caused DNA damage (Zhan 
1998). Much less is known about how environmental stressors, such as salinity and temperature, affect the CSR.

Proliferating Cell Nuclear Antigen (PCNA) is often referred to as the "ringmaster" of the genome (Panesku et al 2001). Both the presence and absence of PCNA in a cell gives insight to the state of that cell. PCNA is necessary in high amounts for cell proliferation and DNA replication, making it a key decider of the fate of a cell. Specifically, PCNA expression has been recorded at high amounts in the last $5 \%$ of the $\mathrm{G}_{1}$-phase, and the first 35\% of the S-phase of the cell cycle (Panesku et al 2001). The concentration of PCNA within a cell is affected by a variety of other proteins. One of these is p53, which binds to the PCNA gene and decrease expression (Panesku et al 2001).

Another way in which p53 can alter PCNA concentration is through the upregulation and subsequent binding of the Growth Arrest and DNA Damage Protein 45alpha (Gadd45-alpha) to the PCNA protein (Chen et al 1995). Gadd45 is regulated by p53 and has the ability to bind to PCNA to form a protein complex (Panesku et al 2001) leading to the inactivation of PCNA. The overexpression of Gadd 45 within a cell can stop cell proliferation (Panesku et al 2001).

Nile Tilapia are an ideal model organism for studying the interactive effect of salinity and decreased temperature. Tropical freshwater species are threatened by increases in salinity levels in traditionally freshwater areas. The natural habitat of the Nile Tilapia would be susceptible to saltwater intrusion due to sea level rise (El-Raey 1997). Nile Tilapia are also one of the aquatic species experiencing Winter Stress Syndrome, which could be made worse due to the fluctuations in temperature as a result of climate change 
(Hurst 2007). While these environmental changes pose large threats to African ecosystems separately, combined the effects could be lethal to many ecosystem inhabitants (Gunter \& Hildebrand 1951). By exposing the Nile Tilapia to a variety of temperature and salinity treatments and measuring changes in protein levels their tolerances can be measured. 


\section{Methodology}

Animals

Animals were reared and exposed to the same treatments detailed in Chapter 2.

\section{Tissue Preparation}

Gill tissues were homogenized in lysis buffer $\left(32 \mathrm{mmol}^{-1}\right.$ Tris- $\mathrm{Cl}, \mathrm{pH}$ 6.8, 0.2\% sodium dodecyl sulfate), boiled for $5 \mathrm{~min}$ at $100^{\circ} \mathrm{C}$, and then centrifuged at $13,000 \mathrm{xg}$ for 10 minutes at room temperature $\left(\sim 20^{\circ} \mathrm{C}\right.$; RT). Supernatants were removed and pellets were discarded. Supernatants were analyzed for total protein content by method of the Bradford assay. Homogenized samples were then stored at $-80^{\circ} \mathrm{C}$.

\section{Western Blotting}

Following Sleadd et al (2014), western blotting was used to ensure the specificity of the antibodies of our proteins of interest. $10 \mu \mathrm{l}$ of total protein from each sample was separated by $10 \%$ gels using SDS-polyacrylamide gel electrophoresis (PAGE). Post separation, the proteins were transferred onto a nitrocellulose membrane by electroblotting overnight at $4^{\circ} \mathrm{C}$ at $30 \mathrm{~V}$. Blots were then soaked for $1 \mathrm{hr}$ in $5 \%$ non-fat dry milk (NFDM) in $1 \mathrm{X}$ PBS while constantly shaking. Blots were washed in $1 \mathrm{X}$ PBS containing $0.01 \%$ Tween 20 for 5 minutes. After 3 washes, primary antibodies (1:1000 dilution in 1 X PBS containing 5\% NFDM) were added, and blots were incubated for overnight in $4^{\circ} \mathrm{C}$. Blots were washed for 10 min in $1 \mathrm{X}$ PBS with $0.1 \%$ Tween 20 . Following three washes, blots were incubated with the secondary a secondary antibody (horseradish peroxidase-conjugated protein A, 170-6522, Bio-Rad) at a 1:6000 dilution in $1 \mathrm{X}$ PBS containing 5\% NFDM. Post- 
incubation blots were washed 3 times in 1 X PBS with $0.01 \%$ Tween 20 for five minutes. Blots were exposed to enhanced chemiluminescent reagent (ThermoFisher) for $5 \mathrm{~min}$. After wrapping the blots in plastic wrap, they were exposed to X-ray film and the film was developed.

\section{Dot Blotting}

Following Buckley et al (2006), dot blots were utilized to determine the differences in concentrations of the proteins of interest. Homogenized gill samples were diluted in 1xPBS (1.16 g Na $2 \mathrm{HPO}_{4}, 0.1 \mathrm{~g} \mathrm{KCl}, 0.1 \mathrm{~g} \mathrm{~K}_{3} \mathrm{PO}_{4}, 4.0 \mathrm{~g} \mathrm{NaCl}, 500 \mathrm{ml}$ distilled water, $\mathrm{pH}$ 7.4) to reach a final concentration of $1.5 \mathrm{ug}$ per $100 \mathrm{ul}$ by using the Bradford Assay. Nitrocellulose membranes were soaked in deionized water for 30 minutes prior to being assembled in the 96-well Bio-Rad dot blot apparatus. $100 \mathrm{ul}$ of sample dilutions were pipetted into each well of the dot blot apparatus. Triplicates were used for each sample. Samples were allowed to sit on the membrane for 30 minutes, then gentle suction was applied to pull excess liquid through the membrane. The membrane was dried for 30 minutes at $70^{\circ} \mathrm{C}$, then was placed in blocking buffer $(5 \%$ Non-Fat Dried Milk in $1 \times$ PBS) for 1 hour at room temperature with constant shaking. Blocking buffer was then removed from the blots, and blots were washed in 1xPBS 3 times for 5 minutes each time. Blots were then incubated with 1:3000 primary antibody (either PCNA, Gadd45 or p53) in blocking buffer overnight at $4{ }^{\circ} \mathrm{C}$ with constant shaking. Primary antibody was then removed from the blot, and the blots were washed 3 times for 10 minutes in 1xPBS. Blots were then incubated in a 1:3000 dilution of secondary antibody (goat anti-Rabbit IgG conjugated to horseradish peroxidase) in blocking buffer for $1 \mathrm{hr}$ at room temperature 
with constant shaking. The secondary antibody was then removed, and blots were washed 6 times for 5 minutes in 1xPBS. Thermo Scientific enhanced chemiluminescent (ECL) was then placed on blots for 5 minutes. Blots were then exposed using x-ray film and the film was developed. Densitometry was then performed.

\section{Densitometry}

To determine protein concentration, dot blots were analyzed in ImageJ (NIH Freeware). Densitometry was performed on each triplicate and averaged. All samples were standardized utilizing control values.

\section{Statistical Analysis}

Data were analyzed using a 2-way ANOVA using R studio software (RStudio, Inc., Boston Massachusetts, USA). To obtain a normal distribution and equal variance, a log transformation was applied to the both the Gadd45 and p53 raw data. To avoid negative values, the value of 1 was added to each sample prior to the log transformations. Data was then analyzed utilizing Tukey Honest Significant Difference (HSD) post hoc test. Results with a p-value $<0.05$ were considered significant and indicated with difference letters in figures. 


\section{Results}

Protein Concentrations

For all experiments, individual triplicate samples were averaged, then averages within treatment groups were averaged to compare average protein concentrations across treatment groups. Comparison across treatment groups gave statistically significant results in all cases. For all experiments, the control group referenced is warm $\left(22^{\circ} \mathrm{C}\right)$ freshwater (0ppt).

Proliferating Cell Nuclear Antigen (PCNA)

Significant changes in PCNA concentration were observed when individuals were subjected to a variety of temperature and salinity treatments, Results described below are based on p-values listed in Table $5 \&$ Figure 3. Within warm water treatments there was a statistically significant decrease in PCNA concentration when exposed to full strength salt-water. There was no significant effect of cold temperature in freshwater. Within cold water treatments, there was no statistically significant effect of brackish water or full strength salt-water. The warm full strength salt-water treatment had statistically significantly lower PCNA concentration when compared to the cold full strength saltwater (34ppt) treatment.

Growth Arrest and DNA Damage Protein 45-alpha (Gadd 45)

Significant changes in Gadd45 concentration were observed when individuals were subjected to a variety of temperature and salinity treatments, results described below are based on p-values listed in Table 6, Table 7, Figure 4 \& Figure 5. Results described 
below are referring to p-values obtained by the removal of outliers (Figure 3). Within the warm water treatments there was no statistically significant effect of brackish water. However, there was a statistically significant decrease in Gadd45 concentration in response to full strength salt-water when compared to both the brackish water treatment and the control treatment. There was no statistically significant effect of cold treatment in freshwater when compared to the control. Within the cold water treatments, there was no statistically significant differences in response to either brackish water or full strength salt-water.

p53

Significant changes in p53 concentration were observed when individuals were subjected to a variety of temperature and salinity treatments, results described below are based on p-values listed in Table $8 \&$ Figure 6 . There was no significant effect of brackish water in the warm water treatment. A statistically significant decrease was observed in p53 concentration in warm full strength salt-water when compared to the control group. There was no statistically significant effect of cold temperature in the freshwater treatment when compared to the control. Within the cold temperature treatment group, there was no statistically significant effect of either brackish water or full strength salt-water. When comparing brackish water treatments, there is a statistically significant decrease in p53 concentration in the cold water treatment. This significant decrease of cold temperature is no longer observed in the full strength salt-water treatment. 


\section{Discussion}

Global climate change has the potential to completely change the present species assemblages. Physiological studies are crucial to anticipate specific species changes. Due to the potential interaction of multiple abiotic factors, it is important to begin to analyze their combined effect on organisms. By approaching the problem via a holistic physiology approach through considering multiple stressors it allows for better predictions of how species will respond.

In this study of Tilapia, the control group of warm $\left(22^{\circ} \mathrm{c}\right)$ freshwater $(0 \mathrm{ppt})$ was compared to all other treatment groups to analyze how proteins concentrations changed. Nile Tilapia are a euryhaline species, meaning that they can tolerate a variety of salinity levels while maintaining internal plasma osmolality. Brackish water, or $16 \mathrm{ppt}$, is within their range of tolerable salinities which could account for the lack of changes in protein levels within the warm brackish water treatment when compared to the control. However, within the warm water treatments we observed significant decreases in all three proteins when exposed to full strength salt water (34 ppt). These decreases were not only significant in relation to the freshwater treatment ( $0 \mathrm{ppt})$ but also significantly lower than the brackish water treatment as well (16 ppt).

It is interesting to note and all proteins levels decreased in response to full strength salt-water, even though only an increase in p53 was hypothesized due to the fact that increased levels of p53 and decreased levels of PCNA are associated with cell cycle arrest (Panesku et al 2001). Utilizing dot blotting to measure protein levels can only detect to the amount of protein that is physically able to bind to the antibody. Because of 
this, it is possible that the binding of these specific proteins to other sites of interest has prevented them from being available to bind to the antibody.

In a normal cell, the amount of p53 is kept low due to it's half-life of approximately 20 minutes (Levine 1997). Some of this available p53 is also likely in what is known as a latent form (Levine 1997). When this latent p53 is activated through phosphorylation, it is then able to promote continuation through the cell cycle, either through a repair pathway or apoptosis (Levine 1997). In order to initiate the cell cycle arrest pathway, upregulation of Gadd45 occurs. Although we did not test for binding of p53 to any DNA binding site, we hypothesize that this is the reason behind a decrease in p53 concentration. Although there is a strong p53-binding site on the Gadd45 gene, protein-protein interactions between $\mathrm{p} 53$ and Gadd45 can also contribute to positive regulation of the Gadd45 protein within a cell (Zhan et al 1998).

Levels of Gadd45 protein also decreased in Nile Tilapia exposed to warm saltwater. We hypothesize that is again due to the available Gadd45 binding to a target within a cell and a concomitant eliciting of cell cycle arrest. When cell cycle arrest occurs, Proliferating Cell Nuclear Antigen (PCNA) has the ability to form protein complexes with many proteins that are regulated by p53 (Panesku et al 2001). PCNA has a direct binding site for the Gadd45 protein (Chen et al 1995). The binding of Gadd45 to PCNA resulting in a protein complex could stop antibodies from binding to both Gadd45 and PCNA proteins. The blocking of antibody binding to proteins of interest would lead to a decrease in signal when utilizing dot blotting to identify protein concentration.

These changes suggest that while $34 \mathrm{ppt}$ is within the range of salinity tolerances of the Nile Tilapia, a direct transfer which has no acclimation time is stressful enough to 
elicit a response. With acclimation time, Mozambique Tilapia have been shown to tolerate up to $180 \%$ of full strength salt-water (34ppt) (Uchida et al 2000). Due to this ability to tolerate large changes in salinity it suggests that Nile Tilapia may be undergoing the process of gill remodeling rather than cell cycle arrest due to DNA damage. Organisms may begin the process of gill remodeling in response to a change in respiratory requirements (Nilsson 2007). In response to increased salinity, Mozambique Tilapia exhibited highly activated chloride cells in epithelia located in both their branchial and opercular regions (Uchida et al 2000). Nile Tilapia adapted to saltwater conditions were also shown to have an almost 2-fold increase in the amount of $\mathrm{Na}, \mathrm{K}$ ATPase (sodium potassium) pumps in gill tissue when compared to the freshwater adapted individuals (Tsung-Han et al 2003). These findings, in concert with the fact that zero mortality was observed during the tests, suggest that instead of a cellular stress response pathway initiating cell cycle arrest and potentially repair or apoptosis, the changes in protein levels observed in the warm saltwater treatments may be due to gill remodeling.

As ectotherms, changes in environmental temperature have direct impact on changes in internal temperature. Direct transfer of Nile Tilapia from $22^{\circ} \mathrm{c}$ into $14^{\circ} \mathrm{c}$ in freshwater did not significantly impact the protein levels within gill tissue. Increasing salinity within the cold water treatments did not lead to any significant changes in gill protein levels. This may be due to the decreased speed of reactions in colder temperatures, indicating that a longer treatment duration may reveal changes in protein concentrations within this temperature group. Conversely, a lack of protein concentration difference within the cold treatments could suggest that the environmental conditions 
utilized within the study are not drastic enough to elicit a cellular stress response. The lack of response to salinity within the cold temperature treatments could also indicate that the cold treatment is preventing a response to salinity. This study sheds light on the cellular responses of the of a non-mammalian species to environmental changes. 


\section{Figures}

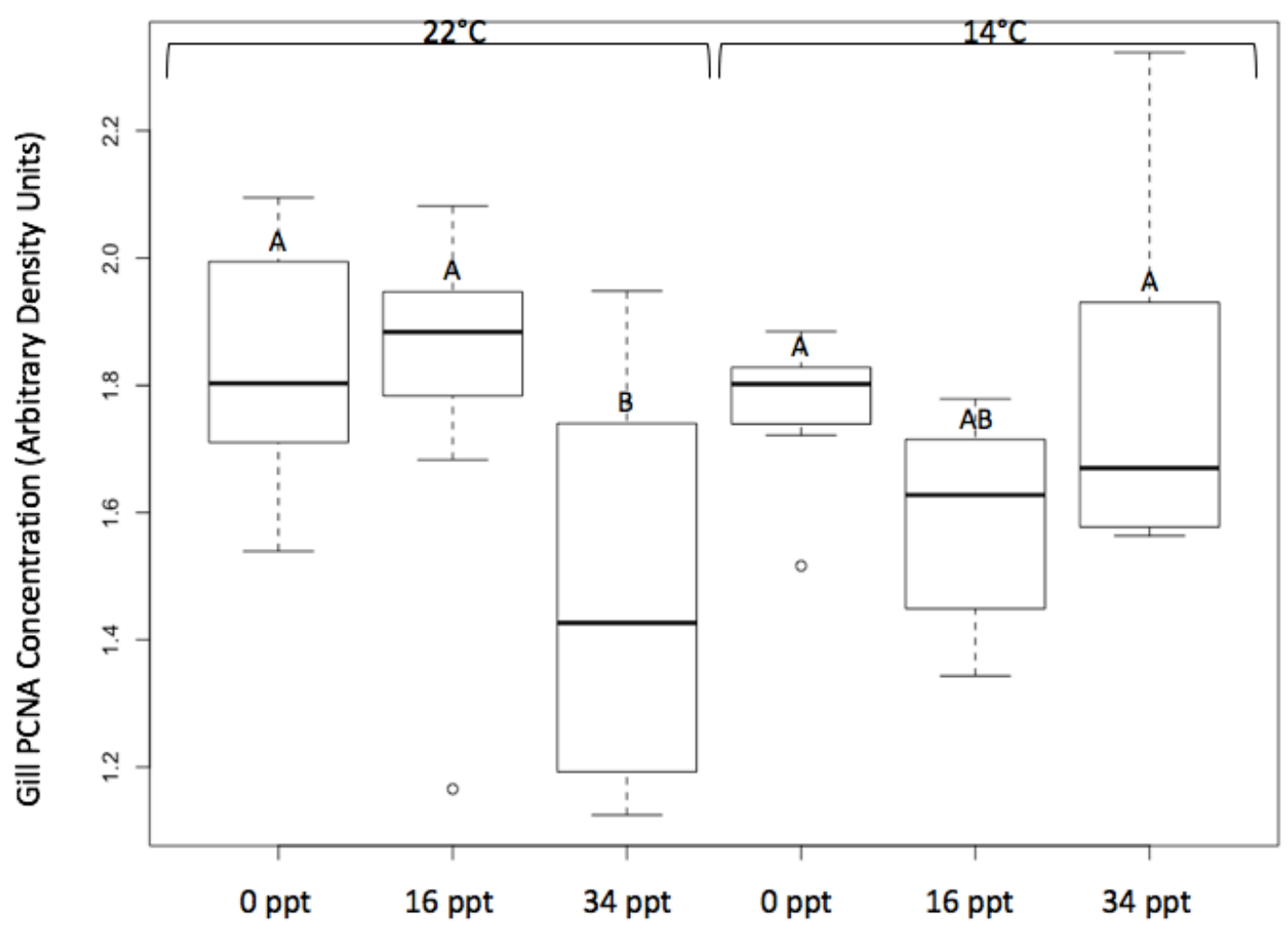

Figure 3: Boxplot of the raw PCNA data from Nile Tilapia (Oreochromis niloticus) gill tissue by treatment group after one hour of exposure. Bold center line represents the median, the bottom and top of the box represent the $25^{\text {th }}$ and $75^{\text {th }}$ percentile respectively, and the whiskers represent the maximum and minimum data points (if there are no outliers). In the presence of outliers, the whiskers represent 1.5 times the Interquartile Range (IQR) away from either the bottom or top of the box. Letters indicate statistically significant differences $(\mathrm{p}<0.05)$.

Table 5: List of all p-values generated from comparing concentration of PCNA in Nile Tilapia (Oreochromis niloticus) gill tissue from each treatment to all other treatments. Bolded values indicate statistically significant values $(\mathrm{p}<0.05)$. Grey boxes indicate repetitive comparisons.

\begin{tabular}{|l|l|l|l|l|l|}
\hline \multicolumn{1}{|c|}{ PCNA } & $21^{\circ} \mathrm{C} / 16 \mathrm{ppt}$ & $21^{\circ} \mathrm{C} / 34 \mathrm{ppt}$ & $14^{\circ} \mathrm{C} / 0 \mathrm{ppt}$ & $14^{\circ} \mathrm{C} / 16 \mathrm{ppt}$ & $14^{\circ} \mathrm{C} / 34 \mathrm{ppt}$ \\
\hline $21^{\circ} \mathrm{C} / 0 \mathrm{ppt}$ & 1.00 & $\mathbf{0 . 0 1 2}$ & 0.998 & 0.217 & 0.999 \\
\hline $21^{\circ} \mathrm{C} / 16 \mathrm{ppt}$ & & $\mathbf{0 . 0 1 1}$ & 0.998 & 0.212 & 0.999 \\
\hline $21^{\circ} \mathrm{C} / 34 \mathrm{ppt}$ & & & $\mathbf{0 . 0 3 8}$ & 0.829 & $\mathbf{0 . 0 3 3}$ \\
\hline $14^{\circ} \mathrm{C} / 0 \mathrm{ppt}$ & & & & 0.441 & 1.00 \\
\hline $14^{\circ} \mathrm{C} / 16 \mathrm{ppt}$ & & & & & 0.410 \\
\hline $14^{\circ} \mathrm{C} / 34 \mathrm{ppt}$ & & & & & \\
\hline
\end{tabular}




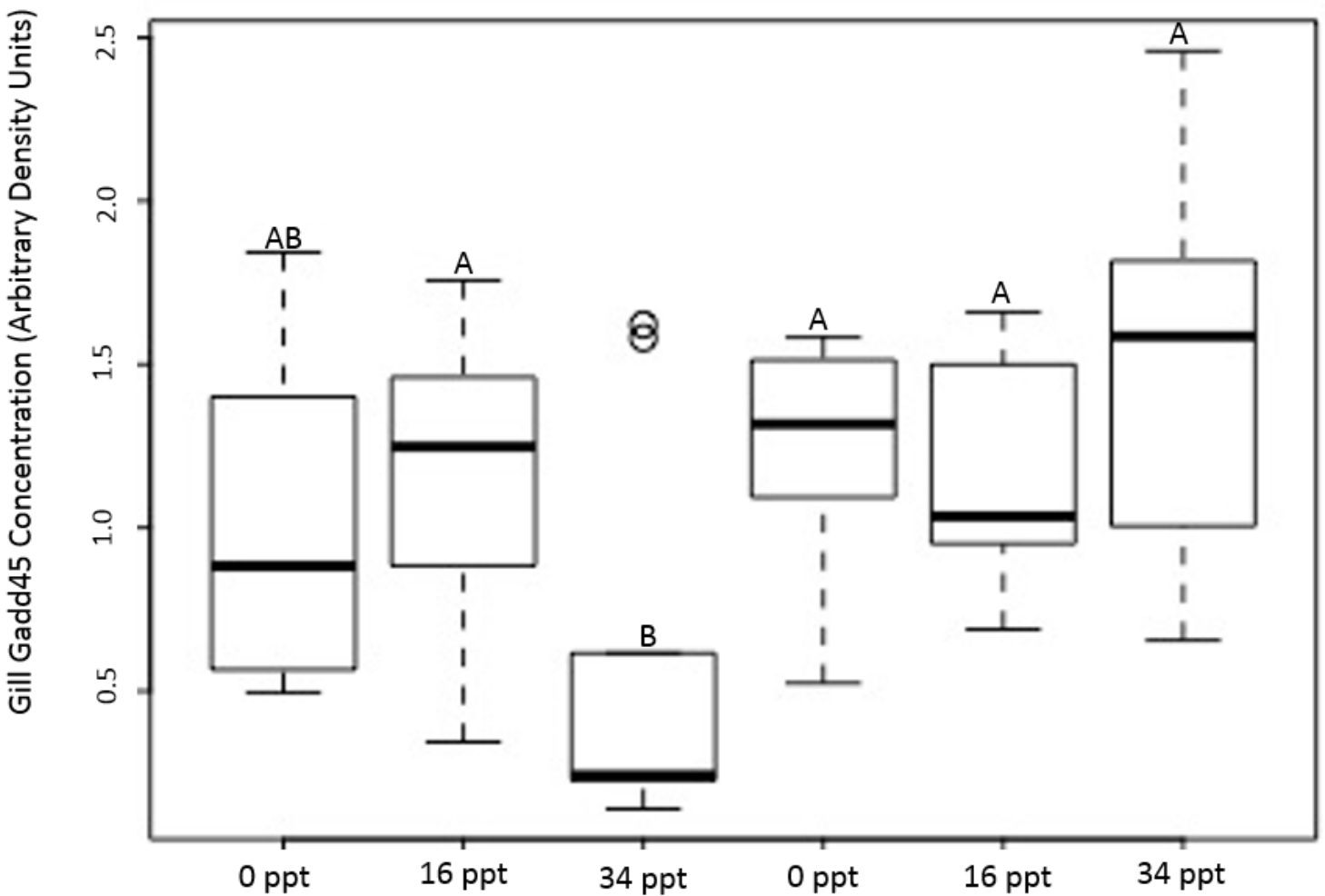

Figure 4: Boxplot of the log transformed Gadd45 data from Nile Tilapia (Oreochromis niloticus) gill tissue by treatment group after one hour of exposure. Bold center line represents the median, the bottom and top of the box represent the $25^{\text {th }}$ and $75^{\text {th }}$ percentile respectively, and the whiskers represent the maximum and minimum data points (if there are no outliers). In the presence of outliers, the whiskers represent 1.5 times the Interquartile Range (IQR) away from either the bottom or top of the box. Letters indicate statistically significant differences $(\mathrm{p}<0.05)$.

Table 6: List of all p-values generated from comparing concentration of Gadd45 in Nile Tilapia (Oreochromis niloticus) gill tissue from each treatment to all other treatments. Bolded values indicate statistically significant values $(\mathrm{p}<0.05)$. Grey boxes indicate repetitive comparisons.

\begin{tabular}{|l|l|l|l|l|l|}
\hline Gadd45.a & $21^{\circ} \mathrm{C} / 16 \mathrm{ppt}$ & $21^{\circ} \mathrm{C} / 34 \mathrm{ppt}$ & $14^{\circ} \mathrm{C} / 0 \mathrm{ppt}$ & $14^{\circ} \mathrm{C} / 16 \mathrm{ppt}$ & $14^{\circ} \mathrm{C} / 34 \mathrm{ppt}$ \\
\hline $21^{\circ} \mathrm{C} / 0 \mathrm{ppt}$ & 0.978 & 0.232 & 0.926 & 0.969 & 0.157 \\
\hline $21^{\circ} \mathrm{C} / 16 \mathrm{ppt}$ & & $\mathbf{0 . 0 4 7}$ & 0.999 & 0.999 & 0.519 \\
\hline $21^{\circ} \mathrm{C} / 34 \mathrm{ppt}$ & & & $\mathbf{0 . 0 2 5}$ & $\mathbf{0 . 0 3 5}$ & $\mathbf{0 . 0 0 0 3}$ \\
\hline $14^{\circ} \mathrm{C} / 0 \mathrm{ppt}$ & & & & 0.999 & 0.675 \\
\hline $14^{\circ} \mathrm{C} / 16 \mathrm{ppt}$ & & & & & 0.593 \\
\hline $14^{\circ} \mathrm{C} / 34 \mathrm{ppt}$ & & & & & \\
\hline
\end{tabular}




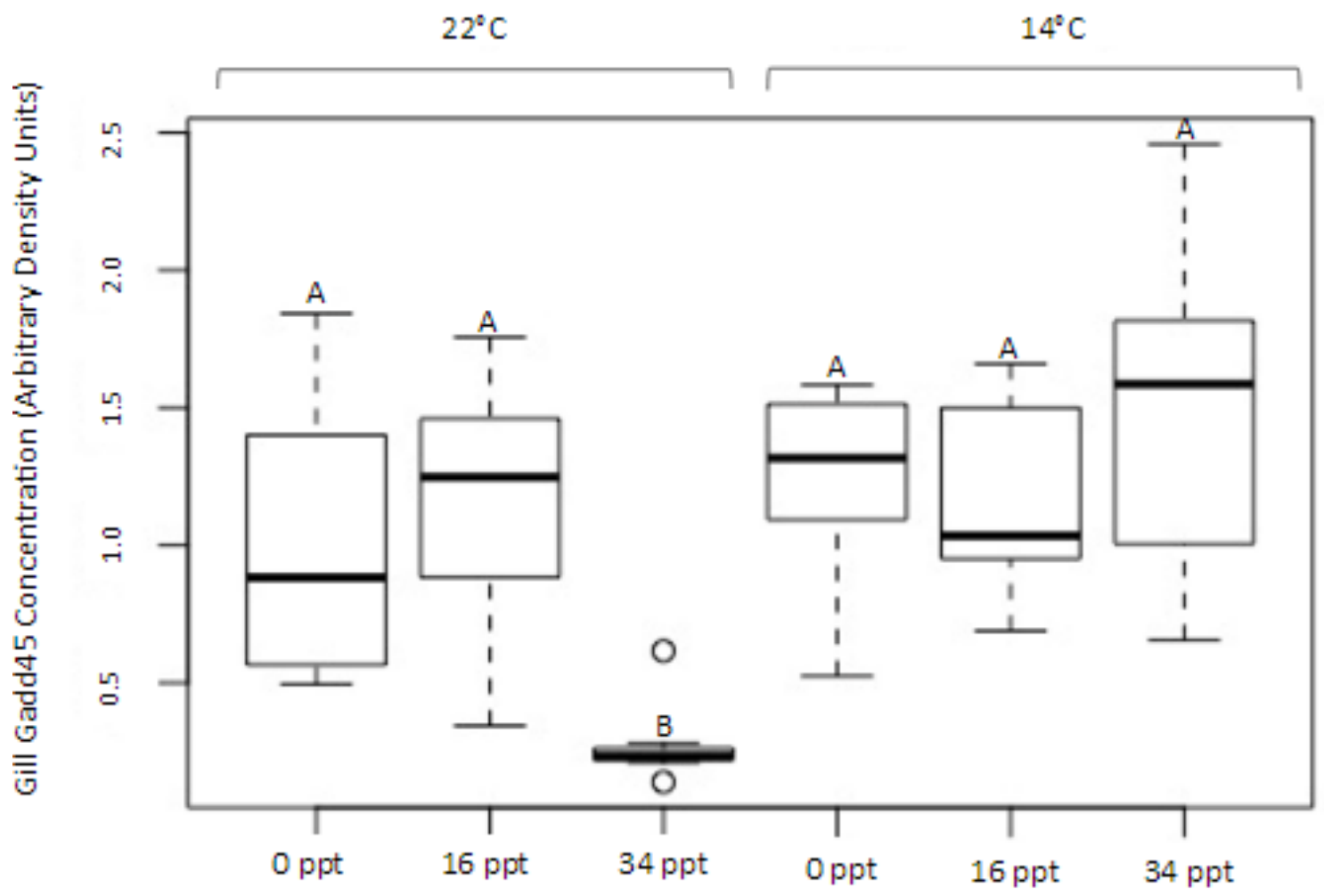

Figure 5: Boxplot of the log transformed Gadd45 data, with largest outliers removed, from Nile Tilapia (Oreochromis niloticus) gill tissue by treatment group after one hour of exposure. Bold center line represents the median, the bottom and top of the box represent the $25^{\text {th }}$ and $75^{\text {th }}$ percentile respectively, and the whiskers represent the maximum and minimum data points (if there are no outliers). In the presence of outliers, the whiskers represent 1.5 times the Interquartile Range (IQR) away from either the bottom or top of the box. Letters indicate statistically significant differences $(\mathrm{p}<0.05)$.

Table 7: List of all p-values generated from comparing concentration of Gadd45 in Nile Tilapia (Oreochromis niloticus) gill tissue from each treatment to all other treatments, with outliers removed.

Bolded values indicate statistically significant values $(\mathrm{p}<0.05)$. Grey boxes indicate repetitive comparisons.

\begin{tabular}{|l|l|l|l|l|l|}
\hline Gadd45.b & $21^{\circ} \mathrm{C} / 16 \mathrm{ppt}$ & $21^{\circ} \mathrm{C} / 34 \mathrm{ppt}$ & $14^{\circ} \mathrm{C} / 0 \mathrm{ppt}$ & $14^{\circ} \mathrm{C} / 16 \mathrm{ppt}$ & $14^{\circ} \mathrm{C} / 34 \mathrm{ppt}$ \\
\hline $21^{\circ} \mathrm{C} / 0 \mathrm{ppt}$ & 0.963 & $\mathbf{0 . 0 0 6}$ & 0.882 & 0.932 & 0.079 \\
\hline $21^{\circ} \mathrm{C} / 16 \mathrm{ppt}$ & & $\mathbf{0 . 0 0 0 4}$ & 0.999 & 0.999 & 0.384 \\
\hline $21^{\circ} \mathrm{C} / 34 \mathrm{ppt}$ & & & $\mathbf{0 . 0 0 0 2}$ & $\mathbf{0 . 0 0 0 3}$ & $7.0 \times 10^{-7}$ \\
\hline $14^{\circ} \mathrm{C} / 0 \mathrm{ppt}$ & & & & 0.999 & 0.554 \\
\hline $14^{\circ} \mathrm{C} / 16 \mathrm{ppt}$ & & & & & 0.462 \\
\hline $14^{\circ} \mathrm{C} / 34 \mathrm{ppt}$ & & & & & \\
\hline
\end{tabular}




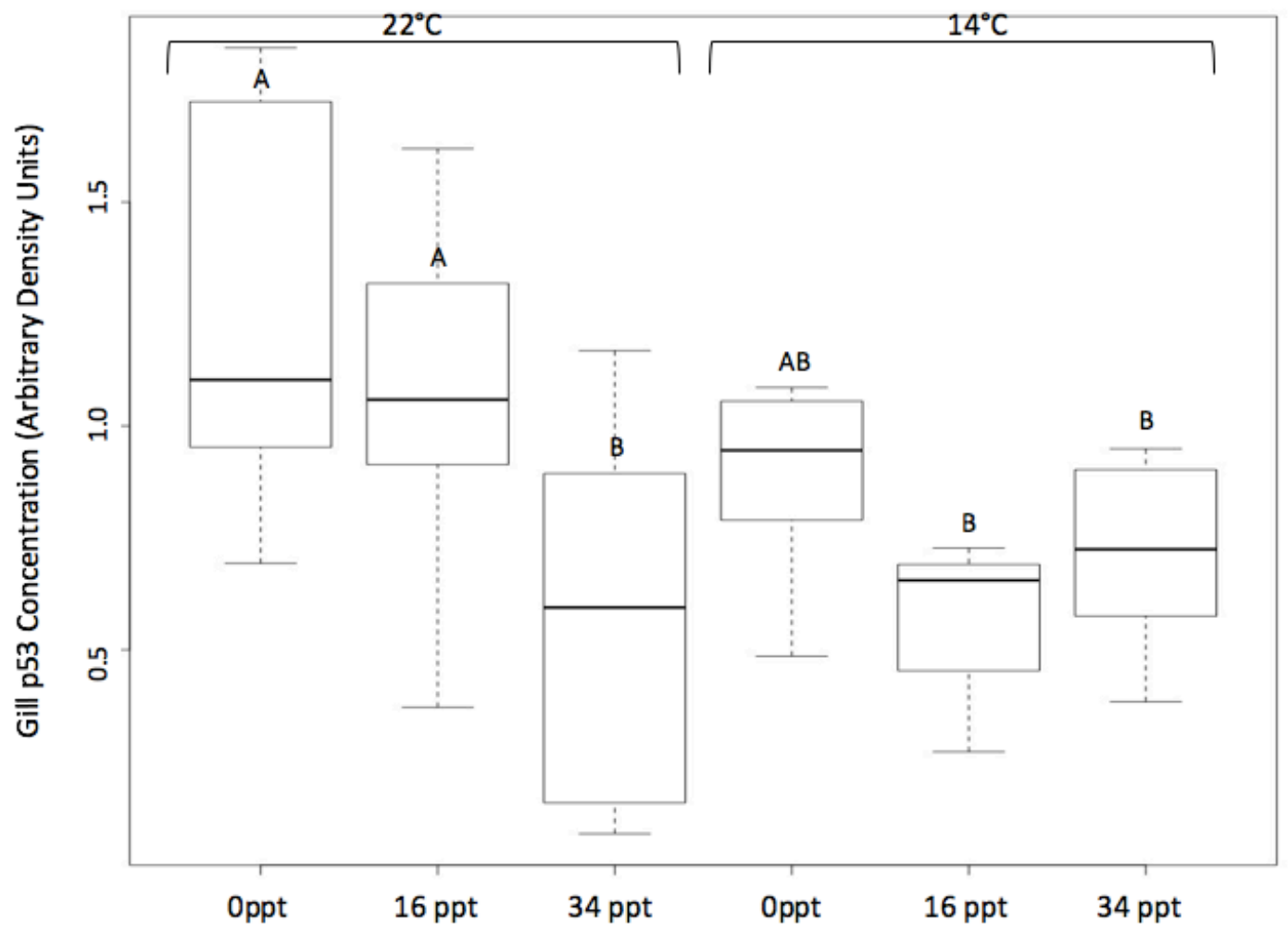

Figure 6: Boxplot of the log transformed p53 data from Nile Tilapia (Oreochromis niloticus) gill tissue by treatment group after one hour of exposure. Bold center line represents the median, the bottom and top of the box represent the $25^{\text {th }}$ and $75^{\text {th }}$ percentile respectively, and the whiskers represent the maximum and minimum data points (if there are no outliers). In the presence of outliers, the whiskers represent 1.5 times the Interquartile Range (IQR) away from either the bottom or top of the box. Letters indicate statistically significant differences $(\mathrm{p}<0.05)$.

Table 8: List of all p-values generated from comparing concentration of p53 in Nile Tilapia (Oreochromis niloticus) gill tissue from each treatment to all other treatments. Bolded values indicate statistically significant values $(\mathrm{p}<0.05)$. Grey boxes indicate repetitive comparisons.

\begin{tabular}{|l|l|l|l|l|l|}
\hline \multicolumn{1}{|c|}{$\mathbf{p 5 3}$} & $21^{\circ} \mathrm{C} / 16 \mathrm{ppt}$ & $21^{\circ} \mathrm{C} / 34 \mathrm{ppt}$ & $14^{\circ} \mathrm{C} / 0 \mathrm{ppt}$ & $14^{\circ} \mathrm{C} / 16 \mathrm{ppt}$ & $14^{\circ} \mathrm{C} / 34 \mathrm{ppt}$ \\
\hline $21^{\circ} \mathrm{C} / 0 \mathrm{ppt}$ & 0.734 & $\mathbf{0 . 0 0 0 3}$ & 0.144 & $\mathbf{0 . 0 0 0 1}$ & $\mathbf{0 . 0 0 3}$ \\
\hline $21^{\circ} \mathrm{C} / 16 \mathrm{ppt}$ & & $\mathbf{0 . 0 2 5}$ & 0.877 & $\mathbf{0 . 0 1 1}$ & 0.136 \\
\hline $21^{\circ} \mathrm{C} / 34 \mathrm{ppt}$ & & & 0.295 & 0.999 & 0.981 \\
\hline $14^{\circ} \mathrm{C} / 0 \mathrm{ppt}$ & & & & 0.170 & 0.717 \\
\hline $14^{\circ} \mathrm{C} / 16 \mathrm{ppt}$ & & & & & 0.918 \\
\hline $14^{\circ} \mathrm{C} / 34 \mathrm{ppt}$ & & & & & \\
\hline
\end{tabular}




\section{Chapter 4: The response of CCAAT/enhancer binding protein- $\delta(\mathrm{C} / \mathrm{EBP}-\delta)$ to salinity and temperature in Nile Tilapia, Oreochromis niloticus. \\ Abstract}

Fluctuations in abiotic factors are increasing as global climate change progresses.

In order to compensate for these changes organisms may rely upon the cellular stress response. The CCAAT/Enhancer-binding proteins (C/EBP) are a class of transcription factors that act upon cellular proliferation and differentiation. $\mathrm{C} / \mathrm{EBP}-\delta$ is the specific protein that is activated in response to stress stimuli. Several studies have investigated the role of heat stress on $\mathrm{C} / \mathrm{EBP}-\delta$ levels, however the effects of other environmental stressors are widely unknown.

This study investigated the response of $\mathrm{C} / \mathrm{EBP}-\delta$ levels to a variety of cold temperature and salinity treatments in the Nile Tilapia (Oreochromis niloticus). After one hour of exposure, gill tissues were collected for 10 individuals per treatment group and $\mathrm{C} / \mathrm{EBP}-\delta$ concentration was assayed utilizing dot-blotting. There were no significant differences observed in $\mathrm{C} / \mathrm{EBP}-\delta$ concentrations in gill tissue. These results indicate that $\mathrm{C} / \mathrm{EBP}-\delta$ may not be activated in response to cold temperature and salinity stress, or that one hour may not be long enough to observe upregulation of $\mathrm{C} / \mathrm{EBP}-\delta$. 


\section{Introduction}

As global climate change progresses, changes in environmental conditions will increase. Over the last 30 years global climate change has increased global temperatures at a rate of $0.2^{\circ} \mathrm{C}$ per decade (Hansen et al 2006). Although global climate change is often thought of as a change in temperature, oxygen availability, $\mathrm{pH}$, and salinity have all been shown to be affected by climate change. Investigating the limitations of an organism to tolerate environmental changes is crucial to understanding how an organism will respond to climate change (Somero 2010). Environmental changes can cause perturbations in the internal environment of an organism. These threats to homeostasis can lead to damage which is managed through cell cycle regulation, most notably the cellular stress response (Kültz 2005).

Not all aspects of the cellular stress response are activated in the same way (Kültz 2005). Damage to macromolecules, such as proteins or DNA, that activate the cellular stress response are not initiated by a specific environmental stress, rather the effect that that stress has on the internal components of a cell (Kültz 2005). Conversely, stress that causes a cellular response that aims to re-establish homeostasis is often stressor specific (Kültz 2005). Extreme changes in environmental conditions can lead to organisms undergoing cell cycle arrest and, if the change is severe enough, even apoptosis. During these stressful environmental conditions, organisms may benefit from halting cellular proliferation and utilizing resources to repair damaged macromolecules (Sleadd et al 2014).

Proteins are often involved in the regulation of the cellular stress response of an organism. There are several notable proteins of interest, but one group in particular is the 
CCAAT/enhancer binding proteins (C/EBP). The C/EBP family are a highly-conserved group of leucine zipper transcription factors that assist in controlling both cellular proliferation and differentiation (Yu et al 2010, Johnson 2005). Within the family there are six different members that range in their expression patterns (Johnson 2005). Both C/EBP- $\alpha$ and C/EBP- $\delta$ are termed "molecular stop signs" due to their anti-proliferation activity for specific cell types (Yu et al 2010). C/EBP- $\delta$ which is an inducible protein that is activated in response to stress stimuli (Johnson 2005).

Environmental stressors have been shown to alter C/EBP- $\delta$ expression in a variety of species and cell types. When mouse mammary epithelial cells enter G0 cell cycle arrest due to serum withdrawal stress, both mRNA and protein C/EBP- $\delta$ levels increased significantly (Johnson 2005). When C/EBP- $\delta$ was forcibly over-expressed in prostate and breast cancer cell lines, a drastic decrease in clonal growth was observed (Ikezoe et al 2005). Previous work in our lab has shown that C/EBP- $\delta$ is up-regulated in response to a heat shock (Buckley 2011, Sleadd \& Buckley 2013). On the other hand, oxidative stress has been shown to up-regulate $\mathrm{C} / \mathrm{EBP}-\delta$ in an inconsistent manor (Hassumani 2013).

The response of C/EBP- $\delta$ to thermal stress due to an increase in temperature has been documented in both a species of goby and an Antarctic fish species (Buckley 2011, Sleadd \& Buckley 2013). The complete pathway of C/EBP- $\delta$ regulation is still undetermined, however, in mammalian systems a pathway for $\mathrm{C} / \mathrm{EBP}-\delta$ has been described in relation to STAT-3 (Clarkson et al 2006). Due to the ability of STAT-3 to modulate Hsp70 and Hsp90, it would reason that C/EBP- $\delta$ expression would be modulated in response to thermal stress (Stephanou \& Latchman 2010). 
The response of heat shock proteins to increased temperatures is well documented, but the heat shock response to low temperature stress and salinity is relatively unknown. This study aims to identify the response of C/EBP- $\delta$ to cold temperature and salinity induced stress. Organisms that are unable to tolerate low temperatures can experience damage to mitochondrial membranes (Schmidt-Nielsen et al 1997). Exposure to increased salinity can lead to changes in internal osmolality, which can denature crucial proteins (Berg et al. 2012). Damage to membranes or proteins can activate the cellular stress response (Kültz 2005). Since C/EBP- $\delta$ is activated in response to stress stimuli (Johnson 2005), I hypothesized that sub-lethal exposures to a variety of thermal and salinity stressors would be reflected in C/EBP- $\delta$ concentrations.

Nile Tilapia (Oreochromis niloticus) were used in this experiment because of their significant economical importance. Previous studies have investigated their tolerance to saline waters and decreased temperatures separately (Hassan et al 2013). It is interesting to note that although these studies aimed to improve growth rates in variable conditions, no studies have examined the response of C/EBP- $\delta$ in the Nile Tilapia. Since C/EBP- $\delta$ plays such a large role in cell cycle regulation (Yu et al 2010), specifically decreasing cellular proliferation, it would be novel to determine whether expression is increased in these environmental conditions. 


\section{Methodology}

Animals

Animals were reared and exposed in the same methods detailed in Chapter 2.

\section{Tissue Preparation}

Tissues were homogenized and prepared in the same methods outlined in Chapter 3.

\section{Custom C/EBP- $\delta$ Antibody}

The antibody used for dot-blotting was custom manufactured in a rabbit. A peptide parallel to the 15 -amino acid sequence off of the $\mathrm{N}$ terminus region of the $\mathrm{C} / \mathrm{EBP}-\delta$ protein from the fish species Gillichthys mirabilis was used as the antigen (Affinity BioReagents, Rockford, IL, USA).

\section{Protein Assessment}

Following methods detailed in Chapter 3, dot blots were assembled and exposed to chemiluminescent. Blots were then imaged using AlphaEase - FluorChem SP (Alpha Innotech Corporation).

\section{Densitometry}

To determine protein concentration, dot blots were analyzed in ImageJ (NIH Freeware). Densitometry was performed on each triplicate to determine the average of a sample. All samples were standardized utilizing control values. 
Statistical Analysis

Data were analyzed using a 2-way ANOVA using the R studio software (RStudio, Inc., Boston Massachusetts, USA). In order to obtain a normal distribution and equal variance, a square root transformation was applied to the data. Data was then re-analyzed utilizing Tukey Honest Significant Difference (HSD) post hoc test. Results with a p-value $<0.05$ were considered significant and indicated with difference letters in figures (Figure 1). 


\section{Results}

$C / E B P-\delta$

The warm freshwater treatment served as the control group in this study since it closely matches the preferred temperature and salinity for the Nile Tilapia. There were no significant changes in $\mathrm{C} / \mathrm{EBP}-\delta$, results described below are based on $\mathrm{p}$-values listed in Table $9 \&$ Figure 7 . Within the warm water treatments there is large variability in C/EBP$\delta$ concentrations, indicating that individual differences are still being observed. There were no significant effects of increasing salinity within the warm temperature treatments $(p>0.05)$. The cold freshwater treatment group also displayed large individual variability, similar to the warm water treatments. However, cold temperature did not elicit any significant changes in $\mathrm{C} / \mathrm{EBP}-\delta$ concentrations $(\mathrm{p}>0.05)$. The individual variability of $\mathrm{C} / \mathrm{EBP}-\delta$ concentration within the cold brackish and cold saltwater treatments decreased. Within the cold treatments, there were no significant differences in relation to salinity changes $(\mathrm{p}>0.05)$. 


\section{Discussion}

A sudden decrease in temperature or salinity alone can be enough to cause cellular damage, let alone a simultaneous change. Most physiological studies aim to better understand how one stressor effects a particular response or pathway, however, it is important to begin to study the interactions of stressors. In one study tidal movement alone was not a significant factor, but when combined with temperature the pair caused a greater effect that temperature alone (Wenger et al 2016). In this study, no significant effect of salinity and temperature on $\mathrm{C} / \mathrm{EBP}-\delta$ concentrations was observed. $\mathrm{C} / \mathrm{EBP}-\delta$ concentrations were not affected by a single stressor or the combination of stressors.

One reason that changed in $\mathrm{C} / \mathrm{EBP}-\delta$ concentrations was not observed could be the duration of the exposures. Previous studies in the laboratory have detected significant changes in C/EBP- $\delta$ concentration after 3 hours of exposure in the goby Gillichthys mirabilis, and after 6 hours of heat stress exposure in the Antarctic fish Trematomus bernacchii (Buckley 2011, Sleadd \& Buckley 2013). Previous studies also examined the effect of increased temperature, whereas this study investigates the effect of decreased temperature and salinity. Nile Tilapia have been observed acclimating to full strength salt-water, indicating that this may not be a stressful enough change to elicit a cellular stress response. When temperature decrease reactions also take longer, so even if 1 hour was long enough to see a response in heat stress, that time may me more than doubled in cold stress.

Another notable facet of these studies was that $\mathrm{C} / \mathrm{EBP}-\delta$ concentrations varied across tissue type. For this study we only measured $\mathrm{C} / \mathrm{EBP}-\delta$ concentrations in gill tissue. While C/EBP- $\delta$ was present in gill tissue of Trematomus bernacchii, the concentration 
was lower than brain, spleen, and white muscle (Sleadd \& Buckley 2013). The time to achieve significant changes in $\mathrm{C} / \mathrm{EBP}-\delta$ concentrations varied across tissue type as well. White muscle was able to obtain significant changes after 3 hours of exposure, but both gill and liver tissue only displayed significant changes after 4 hours of exposure (Buckley 2011).

The heat shock response has been widely documented in a variety of species. However, little is still known about the role of heat shock proteins in cold temperature stress. Since the expression of $\mathrm{C} / \mathrm{EBP}-\delta$ has been linked to heat shock protein activity, uncovering the role of heat shock proteins in cold stress may be a crucial link to understanding how $\mathrm{C} / \mathrm{EBP}-\delta$ will respond. Another possibility is that other cell cycle regulation pathways involved in the cellular stress response are being activated in place of the $\mathrm{C} / \mathrm{EBP}-\delta$ pathway. Lastly, it is possible that the exposures were not stressful enough to trigger activity from the cellular stress response. Nile Tilapia are an extremely hardy species and it is possible that the treatments were not severe enough to cause cell cycle arrest or apoptosis.

The knowledge gained from this study indicate that short term exposures to environmental fluctuation may not elicit a response from $\mathrm{C} / \mathrm{EBP}-\delta$ and other proteins in it's pathway. This could increase the ability to rear Nile Tilapia in a variety of environments, and to invest fewer resources in buffering their environment from fluctuations. The exposures tested closely resembled the conditions off of the North-West Coast of America where Nile Tilapia have yet to be established as an invasive species. Based on the results of this study Nile Tilapia can survive these conditions and therefore stricter regulations may need to be put in place to prevent an invasion of these waters. 
Future directions include increasing the duration of exposure to gain insight whether $\mathrm{C} / \mathrm{EBP}-\delta$ is being upregulated over time. Investigating the responses of other proteins in the pathway, such as STAT-3 and IL-6, could solidify relationships between these proteins and C/EBP- $\delta$. Next studies should also investigate the role of heat shock proteins in response to both cold temperature and increased salinity. 


\section{Figures}

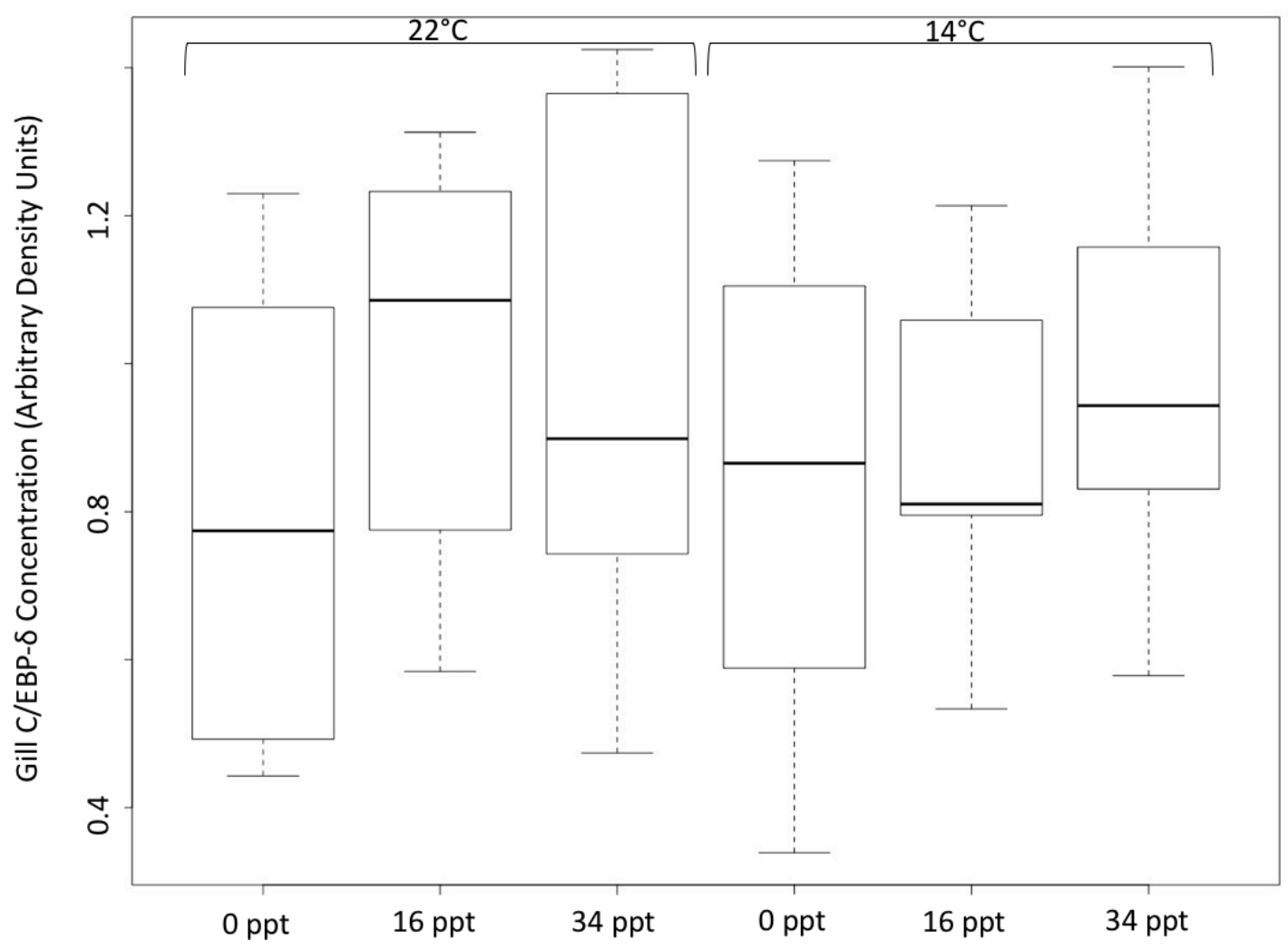

Figure 7: Boxplot of the square root transformed C/EBP- $\delta$ data from Nile Tilapia (Oreochromis niloticus) gill tissue by treatment group after one hour of exposure. Bold center line represents the median, the bottom and top of the box represent the $25^{\text {th }}$ and $75^{\text {th }}$ percentile respectively, and the whiskers represent the maximum and minimum data points (if there are no outliers).

Table 9: List of all p-values generated from comparing concentration of C/EBP- $\delta$ in Nile Tilapia (Oreochromis niloticus) gill tissue from each treatment to all other treatments. Bolded values indicate statistically significant values $(\mathrm{p}<0.05)$. Grey boxes indicate repetitive comparisons.

\begin{tabular}{|l|l|l|l|l|l|}
\hline $\mathrm{C} / \mathrm{EBP}-\delta$ & $21^{\circ} \mathrm{C} / 16 \mathrm{ppt}$ & $21^{\circ} \mathrm{C} / 34 \mathrm{ppt}$ & $14^{\circ} \mathrm{C} / 0 \mathrm{ppt}$ & $14^{\circ} \mathrm{C} / 16 \mathrm{ppt}$ & $14^{\circ} \mathrm{C} / 34 \mathrm{ppt}$ \\
\hline $21^{\circ} \mathrm{C} / 0 \mathrm{ppt}$ & 0.586 & 0.998 & 0.999 & 0.999 & 0.938 \\
\hline $21^{\circ} \mathrm{C} / 16 \mathrm{ppt}$ & & 0.840 & 0.367 & 0.791 & 0.990 \\
\hline $21^{\circ} \mathrm{C} / 34 \mathrm{ppt}$ & & & 0.968 & 0.999 & 0.995 \\
\hline $14^{\circ} \mathrm{C} / 0 \mathrm{ppt}$ & & & & 0.982 & 0.805 \\
\hline $14^{\circ} \mathrm{C} / 16 \mathrm{ppt}$ & & & & & 0.990 \\
\hline $14^{\circ} \mathrm{C} / 34 \mathrm{ppt}$ & & & & & \\
\hline
\end{tabular}




\section{Chapter 5: Conclusions and Future Directions}

Global climate change is altering several abiotic factors simultaneously. While physiological studies are crucial to predicting how species will respond (Somero 2010), most current physiological studies only focus on the response of a species to one stressor. By investigating the interaction between two abiotic factors we can better detect which stressors are limiting. Wenger et al 2016 found that although tidal movement alone was not a significant factor, when tidal movement was combined with temperature the combination was more detrimental than temperature alone.

Although global climate change has increased global temperatures at a rate of $0.2^{\circ} \mathrm{C}$ per decade over the last 30 years, the fluctuations of temperature are also increasing. Mortality in fishes due to cold temperature is a well documented phenomenon known as Winter stress syndrome (Hurst 2007). At the same time, sea level rise is occurring and is introducing salinity and temperature fluctuations (Gunter and Hildebrand 1951).

Nile Tilapia (Oreochromis niloticus) are susceptible to both winter stress syndrome and sea level rise introducing saltwater intrusion on their native habitats (Hassan et al 2013). Tilapia are also an economically important species and a very successful invasive species in their non-native habitats. Because of this, it is crucial to understanding their ability to tolerate a range of environmental conditions in order to a) better adapt their rearing capabilities for optimal growth, and b) provide knowledge to allow for better management to prevent further invasion.

In Chapter 2 I investigated how salinity and temperature affects the cell cycle and potentially cause cell cycle arrest. There were a significantly higher percentage of G2 
cells in the warm saltwater treatment than in the warm brackish water indicating that there might be some cell cycle arrest at the G2 check point occurring. All of the cold water treatments showed a slight decrease of cells in the S phase, and significantly higher proportion of cells in the G2 phase. These results indicate that is cell cycle arrest is occurring at both the G1 and G2 checkpoints.

Changes in the concentration of proteins that assist in the regulation of the cell cycle in response to environmental changes was studied in Chapter 3. Three proteins of interest were studied in this chapter: Proliferating Cell Nuclear Antigen (PCNA) which is necessary in high amounts for cell proliferation and DNA replication, p53 which regulates cell cycle arrest and apoptosis, and Growth Arrest and DNA Damage Protein 45-alpha (Gaff45-alpha) which is up regulated by p53 and binds to PCNA causing it's inactivation. In this study, we found that warm salt-water lead to significant decrease in all protein concentrations. No significant $(\mathrm{p}<0.05)$ changes in any of the protein concentrations occurred with increasing salinity in the cold water treatments.

Other means of controlling cell cycle arrest and apoptosis include the protein family CCAATT/enhancer binding protein (C/EBP). Chapter 4 investigates the response of $\mathrm{C} / \mathrm{EBP}-\delta$ to changes in environmental salinity and temperature. No changes in $\mathrm{C} / \mathrm{EBP}$ $\delta$ were found across any of the treatments: increased salinity, decreased temperature, or the simultaneous exposure to both. Other studies that investigate changes in C/EBP- $\delta$ only see significant concentrations differences after 3 hours, and the duration needed varies with tissue type (Buckley 2011, Sleadd \& Buckley 2013). This indicates that our exposure time of one hour may not have been long enough to observe significant 
changes, that another cell cycle regulation pathway was being activated, or that the stressors were not severe enough to elicit a response.

The combination of flow cytometry results and protein concentrations indicate that the cell cycle arrest being observed is not a direct result of the p53 or C/EBP- $\delta$ pathways. The C/EBP- $\delta$ pathway does not seem to be upregulated after one hour, however, there are significant changes to p53, PCNA and Gadd45 in response to warm saltwater. I hypothesize that these protein changes may not be a result of the cellular stress response, but rather the well documented phenomenon of gill remodeling (Nilsson 2007). The reason for the lack of response to saltwater in the cold may be due to the decreased speed of reactions in cold temperature, or that the cold shock stress response requires too much energy to allocate energy to gill remodeling (Barton \& Schreck 1987).

This study answered several of our research questions, but also left us with new questions to be answered. Although we were excited to document protein and cell cycle changes after only one hour of exposure, we are also interested in the changes over a longer duration. We utilized a direct transfer method to treatment groups in this study, however, acclimating Nile Tilapia to various salinities and testing thermal tolerance could allow for improvement of Tilapia rearing in winter months. Nile Tilapia have already been shown to have increased cold tolerance when acclimated to isotonicity (Hassan et al 2013), however other salinity levels have yet to be investigated.

Comparing the protein and flow cytometry data to plasma cortisol and plasma sodium levels would also be novel. This could provide a direct measure of stress, and how osmoregulatory abilities of individuals are directly affected. Testing the capability of Nile Tilapia variants could also lead to novel findings. A local Nile Tilapia hatchery rears 
Pure-line Nile Tilapia which are known for their salinity tolerance, White Nile Tilapia which are known for an increased cold tolerance, and also offers hybrids. Repeating this experiment and testing each strain separately, then the hybrid could investigate if hybrid species inherit both increased salinity and cold tolerance (NW Tilapia). 


\section{References}

Bakun, A. 1990. Global Climate Change and Intensification of Coastal Upwelling. Science. 247: 198-201.

Barcellos, L. J., Nicolaiewsky, S., De Souza, S. M., \& Lulhier, F. 1999. The effects of stoking density and social interaction on acute stress response in Nile tilapia Oreochromis niloticus (L.) fingerlings. Aquaculture Research. 20: 887-892.

Barton, B. A., \& Schreck, C. B. 1987. Metabolic Cost of Acute Physical Stress in Juvenile Steelhead. Transactions of the American Fisheries Society. 116: 257263.

Berg, J. M., Tymoczko, J. L., \& Stryer, L. (2012). Biochemistry. New York: W.H. Freeman.

Breves, J. P., Hasegawa, S., Yoshioka, M., Fox, B. K., Davis, L. K., Lerner, D. T., Takei, Y., Hirano, T., \& Grau, E.G. 2010. Acute salinity challenges in Mozambique and Nile Tilapia: Differential responses of plasma prolactin, growth hormone and brachial expression of ion transporters. General and Comparative Endocrinology. 167: 135-142.

Buckley, B. A. 2011. Acute heat stress and thermal acclimation induce CCAAT/enhancer-binding protein delta in the goby Gillichthys mirabilis. Journal of Comparative Physiology. 181: 773-780.

Buckley, B. A., Gracey, A. Y., \& Somero, G. N. 2006. The cellular response to heat stress in the goby Gillichthys mirabilis: a cDNA microarray and protein-level analysis. Journal of Experimental Biology. 209: 2660-2677. 
Charo-Karisa, H., Rezk, M. A., Bovenhuis, H., \& Komen, H. 2005. Heritability of cold tolerance in Nile tilapia, Oreochromis niloticus, juveniles. Aquaculture. 249:115-123.

Chebaani, N., Guardiola, F.A., Sihem, M., Nabil, A., Oumouna, M.m Meseguer, J., Esteban, M. A., \& Cuesta, A. 2013. Innate humoral immune parameters in Tilapia zillii under acute stress by low temperature and crowding. Fish Physiology and Biochemistry. 40: 797-804.

Chen, I. T., Smith, M. L., O’Connor, P. M., \& Fornace, A. J. 1995. Direct interaction of Gadd45 with PCNA and evidence for competitive interactive of Gadd45 and p21 Waf1/Cip1 with PCNA. Oncogene. 11: 1931-1937.

Clarkson, R. W. E., Boland, M. P., Kritikou, E. A., Lee, J. M., Freeman T. C., Tiffen, P. G., \& Watson, C. J. 2006. The genes induced by signal transducer and activators of transcription (STAT)3 and (STAT)5 in mammary epithelial cells define the roles of these STATs in mammary development. Molecular Endocrinology. 20: $675-685$.

Elledge, S. J. 1996. Cell Cycle Checkpoints: Preventing an Identity Crisis. Science. 274: $1664-1665$.

El Raey, M., Dewider, Kh., \& El Hattab, M. 1999. Adaptation to the impacts of sea level rise in Egypt. Climate Research. 12: 117-128.

Febry, R. \& Lutz, P. 1986. Energy Partitioning in Fish: The Activityrelated Cost of Osmoregulation in a Euryhaline Cichlid. 128:63-85.

Feely, R. A., Doney, S. C., \& Cooley, S. R. 2009. Ocean Acidification: Present Conditions and Future Changes in a High-CO2 World. Oceanography. 22:36-47. 
Fish. (n.d) (1)In Merriam-Webster's collegiate dictionary. Retrieved from https://www.merriam-webster.com/dictionary/fish.

Fish. (n.d) (2) In English Oxford Dictionary. Retrieved from https://en.oxforddictionaries.com/definition/ fish

Gentile, M., Latonen, L., \& Laiho, M. Cell cycle arrest and apoptosis provoked by UV radiation-induced DNA damage are transcriptionally highly divergent responses. Nucleic Acids Research. 31: 4779-4790.

Grantham, B. A., Chan, F., Nielsen K. J., Fox, D. S., Barth, J. A., Huyer, A., Lubchenco, J., \& Menge, B. A. 2004. Upwelling-driven nearshore hypoxia signals ecosystem and oceanographic changes in the northeast Pacific. Nature. 429: 749754.

Gunter, G., \& Hildebrand, H. H. 1951. Destruction of Fishes and Other Organisms on the South Texas Coast by the Cold Wave of January 28-Februry 3, 1951. Ecology. 32: 731-736.

Hansen, J., Sato, M., Ruedy, R., Lo, K., Lea, D. W., \& Medina-Elizade, M. Global temperature change. 2006. Proceedings of the National Academy of Sciences of the United States of America. 103: 14288-14293.

Hassan, B., El-Salhia, M., Khalifa, A., Assem, H., Al Basomy, A., \& El-Sayed, M. 2013. Environmental isotonicity improves cold tolerance of Nile tilapia, Oreochromis niloticus, in Egypt. The Egyptian Journal of Aquatic Research. 39: 59-65.

Hassumani, D. O. 2013. Expression of Growth Arrest and DNA Damage Protein 45alpha (gadd45-alpha) and the CCAAT/enhancer binding protein delta (C/EBP- 
delta) in Fishes Exposed to Heat and Hypoxia. (unpublished masters thesis, Portland State University)

Hurst, T. P. 2007. Causes and consequences of winter mortality in fishes. Journal of Fish Biology. 71: 315-345.

Ikezoe, T., Gery, S., Yin, D., O’Kelly, J., Binderup, L., Lemp, N., Taguchi, H., \& Koeffler, H. P. 2005. CCAAT/enhancer-binding protein $\delta$ : a molecular target of 1,25-hydroxyvitamin $\mathrm{D}_{3}$ in androgen-responsive prostate cancer LNCaP cells. Cancer Research. 65: 4762-4768.

Johnson, P. F. 2005. Molecular stop signs: regulation of cell-cycle arrest by C/EBP transcription factors. Journal of Cell Science. 118: 2545-2555.

Kroeker, K. J., Kordas, R. L., Crim, R., Hendriks, I. E., Ramajo, L., Singh, G. S., Duarte, C. M., \& Gattuso, J. 2013. Impacts of ocean acidification on marine organisms: quantifying sensitivities and interactions with warming. Global Change Biology. 19:1884-1869.

Krammer, B. D., Cech, J. J., \& Kültz, D. 2010. Rapid changes in plasma cortisol, osmolality, and respiration in response to salinity stress in tilapia (Oreochromis mossambicus). Comparative Biochemistry and Physiology Part A: Molecular \& Integrative Physiology. 157:260-265.

Kültz, D. 2005. Molecular and Evolutionary Basis of the Cellular Stress Response. Annual Review of Physiology. 67: 225-257.

Levine, A. J. 1997. p53, the Cellular Gatekeeper for Growth and Division. Cell. 88: 323331 
Likongwe, J. S., Stecko, T. D., Stauffer, J. R., \& Carline, R. F. 1996. Combined effects of water temperature and salinity on growth and feed utilization of juvenile Nile tilapia Oreochromis niloticus (Linneaus). Aquaculture. 146: 37-46.

Lim, C. \& Webster, C. D. 2006. Tilapia: Biology, Culture and Nutrition. Food Products Press, an imprint of The Hawthorne Press.

Linke, S. P., Clarkin, K. C., Leonardo, A. D., Tsou, A., \& Wahl, G. M. A reversible, p53 dependent $\mathrm{G}_{0} / \mathrm{G}_{1}$ cell cycle arrest induced by ribonucleotide depletion in absence of detectable DNA damage.

Maule, A. G., Tripp, R. A., Kaattari, S. L., and Schreck, C. B. 1989. Stress alters immune function and disease resistance in chinook salmon (Oncorhynchus tshawytscha). Journal of Endocrinology. 120: 135-142.

McCormick, S. D., Shrimpton, J. M., Carey, J. B., O’Dea, M. F., Sloan, K. E., Moriyama, S., \& Björnsson, B. Th. 1998. Repeated acute stress reduces growth rate of Atlantic salmon parr and alters plasma levels of growth hormone, insulin-like growth factor I and cortisol. Aquaculture. 18: 221-235.

Murray, A. W. Creative blocks: cell-cycle checkpoints and feedback controls. Nature. 359: 599-604.

Nilsson, G. E. 2007. Gill remodeling in fish - a new fashion or an ancient secret? Journal of Experimental Biology. 210: 2403-2409.

NW Tilapia. In NW Tilapia webpage “Our Breeds". Retrieved from http://www.nwtilapia.com/ourbreeds.html

Pachauri, R. 2007. Climate Change 2007: Synthesis Report. IPCC Secretariat, Geneva. 
Paunesku, T., Mittal, S., Protić, M., Oryhon, J., Korolev, S. V., Joachimiak, A., \& Woloschak, G. E. 2001. Proliferating cell nuclear antigen (PCNA): ringmaster of the genome. International journal of radiation biology. 77: 1007-1021.

Ries, J. B., Cohen, A. L., \& McCorkle, D. C. 2009. Marine calcifiers exhibit mixed responses to CO-induced ocean acidification. Geology. 37:1131-1134.

Schafer, K. A. 1998. The Cell Cycle: A Review. Veterinary Pathology. 35: 461-478.

Schmidt-Nielsen, K. 1997. Animal physiology: adaptation and environment. $5^{\text {th }}$ edition. Cambridge Press.

Schreck, C. B., Contreras-Sanchez, W., \& Fitzpatrick, M. S. 2001. Effects of stress on fish reproduction, gamete quality, and progeny. Aquaculture. 197: 3-24.

Schreck C. B. 2009. Stress and fish reproduction: The roles of allostasis and homesis. General and Comparative Endocrinology. 165: 549-556.

Sleadd, I. M., \& Buckley, B. A. 2012. The CCAAT/enhancer-binding protein $\delta$ (C/EBP$\delta)$ transcription factor is heat inducible in the cold-adapted antarctic fish Trematomus bernacchii. Polar Biology. 36: 335-342.

Sleadd, I. M, Lee, M., Hassuamani, D. O., Stecyk, T., Zeitz, O. K., \& Buckley, B. A. 2014. Sub-lethal heat stress causes apoptosis in an Antarctic fish that lacks an inducible heat shock response. Journal of Thermal Biology. 44: 119-125.

Somero, G. N. 2010. The physiology of climate change: how potentials for acclimatization and genetic adaptation will determine 'winners' and 'losers'. Journal of Experimental Biology. 213: 912-920.

Stephanou, A., \& Latchman D. S. 2010. Transcriptional Modulation of Heat-Shock Protein Gene Expression. Biochemistry Research International. 2011: 1-8. 
Strange, R. J., Schreck, C. B., \& Golden, J. T. 2011. Corticoid Stress Responses to Handling and Temperature in Salmonoids. Transactions of the American Fisheries Society. 106: 213-218.

Tsung-Han, L., Shin-Huey, F., Chia-Hao, L., Yu-Hwa, H., Chao-Lu, H. \& Pung-Pung, H. 2003. Ambient Salinity Modulates the Expression of Sodium Pumps in Branchial Mitochondria-Rich Cells of Mozambique Tilapia, Oreochromis mossambicus. Zoological Science. 20: 29-36.

Uchida, K., Kaneko, T., Miyazaki, H., Hasegawa, S., \& Hirano, T. 2000. Excellent Salinity Tolerance of Mozambique Tilapia (Oreochromis mossambicus): Elevated Chloride Cell Activity in the Branchial and Opercular Epithelia of Fish Adapted to Concentrated Seawater. Zoological Science. 17: 149-160.

Wenger, A. S., Whinney, J., Taylor, B., \& Kroon, F. 2016. The impact of individual and combined abiotic factors on daily otolith growth in a coral reef fish. Scientific Reports. 6:28875.

Yamamoto, K., Itazawa, Y., \& Hiroshi K. 1985. Direct Observation of Fish Spleen by Abdominal Window Method and Its Application to Exercised and Hypoxic Yellowtail. Japanese Journal of Ichthyology. 31: 427-433.

Yu, X., Si, J., Zhang, Y., \& DeWille, J. W. 2010. CCAAT/Enhancer Binding Proteindelta (C/EBP-delta) regulates cell growth, migration and differentiation. Cancer Cell International. 10:48.

Zhan, Q., Chen, I. T., Antinore, M. J., \& Fornace, A. J. 1998. Tumer Suppresor p53 Can Participate in Transcriptional Induction of the Gadd45 Promoter in the Absence of Direct DNA Binding. Molecuar and Cellular Biology. 18: 2768-2778. 